\title{
Koligacje rodzinne Przemyślidów opawskich linii raciborskiej z możnowładztwem Królestwa Polskiego do początku XVI wieku
}

W 1337 roku Mikołaj II, książę opawski, przy wsparciu króla Czech Jana Luksemburskiego, przejął księstwo raciborskie po wymarciu tamtejszej linii Piastów, dając początek księstwu opawsko-raciborskiemu. Czterdzieści lat później, w 1377 roku, jego synowie podzielili księstwo. W wyniku tego podziału Jan I przejął część raciborską i z części opawskiej Karniów (Jägerndorf) oraz Bruntal (Freudenthal), natomiast jego młodszym braciom przypadły Opawa i Głubczyce, połączone po pewnym czasie przez jednego z nich, Przemka, w księstwo opawskie'. W efekcie ukształtowały się dwie linie Przemyślidów: raciborsko-karniowska i opawska².

${ }^{1}$ LBS, T. 2, s. 484 - 493; J. DĄBRowsKi: Dzieje polityczne Śląska w latach 1290—1402. W: Historia Śląska od najdawniejszych czasów do 1400 r. Red. S. KutrzeBA. T. 1. Kraków 1933, s. 374-375; D. Prix: Vévoda Václav I. Opavský. Příspěvek k dějnám Opavského vévodstvípočátkem posledni čtvrtiny 14. století. „Acta historica et museologica Universitatis Silesiane Opaviensis" 1997, 3, s. 54-89; J. Šusta: Počátky Lucemburské 1308-1320. Dvě knihy českých dějin. Kus středověké historie našeho kraje. Kniha 2. Vyd. 3. Praha 2002, s. 148-151.

${ }^{2}$ W następnych latach książęta linii raciborsko-karniowskiej tytułowali się książętami Opawy i Raciborza (dux Oppavie et Ratiborie; Herzog zu Troppaw und zu Rathibor). Czynili to, mimo że nie posiadali Opawy, a niektórzy z nich także Raciborza, co było wynikiem dalszych podziałów dynastyczno-terytorialnych. Do tej tytulatury dodawano często nazwę posiadanego dominium, np. pana na Karniowie, Rybniku czy Pszczynie - zob. na ten temat: I. PietrzyK: Kancelaria i dokument Przemyślidów opawskich w XIV-XV wieku. Katowice 2008, s. 66-67; J. SPERKA: Tragiczne losy księcia rybnickiego Wactawa III (zm. 1478). Epizod 
Spośród księstw władanych przez Przemyślidów z Królestwem Polskim bezpośrednio graniczyło księstwo raciborskie. Skutkowało to intensywnymi kontaktami na wielu polach - politycznym, gospodarczym, społecznym i kościelnym (wschodnia część księstwa wchodziła w skład diecezji krakowskiej). Niewątpliwie jednym $\mathrm{z}$ efektów tej sytuacji były małżeństwa zawierane od końca XIV do początku XVI wieku między książętami raciborskimi — najpierw z domem Jagiellonów, później $\mathrm{z}$ reprezentantami polskich rodzin możnowładczych, a w jednym przypadku także z przedstawicielką mieszczaństwa krakowskiego ${ }^{3}$.

Związki rodzinne $\mathrm{z}$ dynastią panującą w Polsce zapoczątkował syn księcia Jana I Janusz (Jan) II Żelazny (1382-1424), który dwukrotnie żenił się z kobietami z familii Giedyminowiców. Wpisywało się to zresztą w strategię króla Władysława Jagiełły, który prowadził przemyślaną politykę małżeńską wobec książąt górnośląskich, wiążąc przedstawicieli swojej rodziny z reprezentantami poszczególnych linii dynastycznych, aby pozyskać ich dla swoich celów. $\mathrm{Z}$ tą polityką niewątpliwie należy też łączyć niektóre związki możnowładczo-książęce, a najlepszym przykładem były małżeństwa Jadwigi, córki wojewody krakowskiego Spytka z Melsztyna, z Bernardem, księciem opolskim, (1401) i Elżbiety Granowskiej, pasierbicy króla, z Bolkiem V opolskim (1417), które miały zneutralizować wrogą Królestwu postawę tej linii Piastów ${ }^{4}$.

Małżeństwa Janusza II Żelaznego były już analizowane w literaturze historycznej. W związku z tym jedynie przypomnę, że jego pierwszą żoną została

z dziejów rywalizacji między Jagiellonami a Maciejem Korwinem o koronę czeską. „Studia z Dziejów Średniowiecza" 2016, T. 20, s. 257-258.

${ }^{3} \mathrm{Na}$ temat małżeństwa Mikołaja raciborskiego, pana na Rybniku i Karniowie, z Barbarą Rokenberg, mieszczką krakowską, zob. J. SPERKA: Małżeństwa Mikołaja V księcia opawsko-raciborskiego, pana na Rybniku (zm. 1452 r.). W: Silesia - Polonia - Europa. Studia historyczne dedykowane Profesorowi Idziemu Panicowi. Red. J. Sperka. Bielsko-Biała—Cieszyn 2019, s. 247-259.

${ }^{4} \mathrm{Na}$ temat polityki małżeńskiej króla Władysława Jagiełły wobec książąt śląskich zob. J. TĘGowski: Małżeństwo Wigunta Olgierdowicza w politycznych planach króla Władysława Jagietty. W: „Genealogia. Studia i Materiały Historyczne”. Red. M. GóRny. T. 7. Wrocław 1996, s. 65-67; J. TĘGOWsKI: Władcy śląscy w polityce matżeńskiej króla Władysława Jagietty (1386-1412). W: Piastowie w kulturze i europejskich dziejach. Red. A. BARCIAK. Katowice 2007, s. 232-244; J. Tદ̨Gowski: Pierwsze pokolenia Giedyminowiczów. Poznań-Wrocław 1999, s. 85, 113, 153-154, 160, 242; J. SPERKA: Władysław ksiaże opolski, wieluński, kujawski, dobrzyński, pan Rusi, palatyn Węgier i namiestnik Polski (1326/1330-8 lub 18 maja 1401). Kraków 2012, s. 60; TenżE: Pszczyna i ziemia pszczyńska — dzieje polityczne do 1517 roku. W: Pszczyna. Monografia historyczna. Red. R. Kaczmarek, J. Sperka. T. 1. Pszczyna 2014, s. 89-90; J. SPERKA: Związi rodzinne króla Władysława Jagietly z książętami górnośląskimi $i$ Luksemburgami w tle. W: Ojcowie i synowie. O tron, władze, dziedzictwo. W 700. rocznice narodzin Karola IV Luksemburskiego króla czeskiego i cesarza 1316-1378. Red. B. MożEJKO, A. PANER. Gdańsk 2018, s. 186-198; J. SPERKA: Jeszcze raz o okolicznościach zawarcia matżeństwa między Jadwiga Melsztyńska i księciem opolskim Bernardem. W: Inter Regnum et Ducatum. Studia ofiarowane Profesorowi Janowi Tęgowskiemu w siedemdziesiąta rocznice urodzin. Red. P. Guzowski, M. LiedKe, K. Boroda. Białystok 2018, s. 523—534. 
nieznana nam z imienia córka Włodzimierza, księcia kijowskiego, siostrzenica króla Władysława Jagiełły, a małżeństwo zawarto w 1394 roku albo tuż przed tym rokiem ${ }^{5}$. Po jej śmierci drugą żoną została w 1407 roku Helena, córka Dymitra Korybuta, księcia nowogrodzkiego, bratanica króla Jagiełły 6 . Z Wilna do Pszczyny, gdzie czekał na nią książę, przywiózł ją biskup krakowski Piotr Wysz. Jeszcze w tym roku (1407) książę zapisał jej wiano w wysokości 3 tysięcy grzywien zabezpieczonych na dobrach w ziemi pszczyńskiej, a zapis zatwierdził senior księcia Wacław IV, król Czech7 . Z tego małżeństwa pozostało dwóch synów i córka. Pierworodnym był Mikołaj, który urodził się w 1409 roku$^{8}$. Młodszy z braci, Wacław, przyszedł na świat prawdopodobnie w 1410 roku, ale niewykluczone, że stało się to kilka lat później (jednak nie dalej niż w 1419 roku) ${ }^{9}$, gdyż dzieckiem pary książęcej była jeszcze Małgorzata, później żona Kazimierza oświęcimskiego, a następnie Siemowita V mazowieckiego ${ }^{10}$, która urodziła się w tej dekadzie.

W sprawach matrymonialnych przedstawiciele trzech następnych pokoleń po Januszu Żelaznym (zm. 12 sierpnia 1424) poszli w jego ślady i znaleźli sobie żony lub mężów w Królestwie Polskim. I tej problematyce, ograniczonej jednak do kręgu możnowładczego, zamierzam poświęcić niniejszy artykuł ${ }^{11}$.

5 J. TęGowski: Pierwsze pokolenia Giedyminowiczów..., s. 85. Stryj Janusza Żelaznego Przemek opawski poślubił natomiast w 1386 r. Annę, córkę Lubarta, księcia łuckiego, a siostrę Fiodora łucko-włodzimierskiego. Małżeństwo miało jednak wydźwięk anty-Jagiełłowy M. ČAPSKÝ: Vévoda Přemek Opavský (1366-1433). Ve službách posledních Lucemburki̊. Brno-Opava 2005, s. 70-71; zob. też J. TĘGOWski: Władcy ślascy w polityce matżeńskiej..., s. 234.

6 J. TęGowski: Pierwsze pokolenia Giedyminowiczów..., s. 113.

7 Silesiacarum rerum Scriptores. Hrsg. F.W. SommersBerg. Bd. 1-2. Lipsiae 17291730 (dalej: SRS Sommersberg), s. 951; KDP, T. 4, nr 15, 16, 17. Szczegółowo na temat zapisu wiana zob. J. Sperka: Pszczyna i ziemia pszczyńska..., s. 89-90.

${ }^{8}$ Ratiborer Chronik. Hrsg. A. Weltzel. „Zeitschrift des Vereins für Geschichte und Alterthum Schlesiens" (dalej: ZVGAS) 1862, Bd. 4, s. 116; J. SPERKA: Pszczyna i ziemia pszczyńska..., s. 90 - 92. Błędną datę urodzin księcia Mikołaja — ok. 1400 r. — podaje F. СносноLATÝ: Genealogie opavských Přemyslovců 1255-1525. „Listy Genealogické a Heraldické Společnosti v Praze. Acta Genealogica ac Heraldica“ 1978, ř. 6, s. 150.

9 Terminus ante quem wynika z faktu, że w 1437 r. doszło między braćmi do podziału księstwa, książę Mikołaj powinien więc mieć wtedy nie mniej niż 18 lat, a zatem urodzić się najpóźniej w 1419 r.

${ }^{10} \mathrm{Na}$ temat Małgorzaty, córki Janusza II Żelaznego, zob. K. JAsıŃski: Rodowód Piastów śląskich. Kraków 2007, s. 635; Tenże: Rodowód Piastów mazowieckich. Poznań-Wrocław 1998, s. 110-111; J. Grabowski: Genealogia Piastów mazowieckich. Studia nad dziejami politycznymi Mazowsza, intytulacją i genealogia książą. Kraków 2012, s. 463-464. Błędną datę urodzin księcia Wacława - ok. 1405 r. - podaje F. СносноцAтÝ: Genealogie opavských Přemyslovců..., s. 151 (za nim także autorzy komentarzy w: Annales, lib. 12 [2005], s. 486, przyp. 151 = Roczniki, ks. 12 [2006], s. 109, przyp. 145).

${ }^{11}$ W tym miejscu warto wspomnieć, że opawska linia Przemyślidów doczekała się ostatnio nowych opracowań dotyczących problematyki matrymonialno-genealogicznej, zob.: 
Pierwszym z Przemyślidów, który wszedł w związki rodzinne z możnowładztwem polskim, żeniąc się z Małgorzatą Szamotulską, był Wacław raciborski. Zanim to nastąpiło, po śmierci Janusza Żelaznego z uwagi na nieletniość jego synów rządy w księstwie sprawowała Helena. Wkrótce do współrządów dopuściła starszego syna - Mikołaja, ale na wystawianych wtedy dokumentach, u ich boku, występował od początku także młodszy - Wacław; pierwszy raz odnotowany został 13 września $1424 \mathrm{roku}^{12}$. Natomiast od 1428 roku, kiedy Helena osiadła w swoich dobrach oprawnych, w ziemi pszczyńskiej, Wacław współrządził ze starszym bratem Mikołajem w księstwie raciborskim ${ }^{13}$. W niedziale braterskim książęta funkcjonowali aż do 15 października 1437 roku. Wtedy to - za pośrednictwem dziewięciu rycerzy reprezentujących ziemię raciborską, karniowską i rybnicką — przeprowadzili podział. W jego wyniku Wacławowi przypadła mniejsza część księstwa, ale z bogatym Raciborzem i przynależnym okręgiem, oraz Żytna i Pilchowice, leżące w okręgu rybnickim (wsie były rekompensatą za Tworków położony w okręgu raciborskim, którego właściciel Janusz (Hanusz) Klemma z Ligoty podlegał władzy księcia Mikołaja). Z kolei Mikołaj zatrzymał: Karniów, Bruntal, Baborów, Rybnik i Wodzisław z przynależnymi dystryktami. Jego władzy miała w przyszłości podlegać również Pszczyna, którą dożywotnio dzierżyła matka - Helena ${ }^{14}$.

Wybranka Wacława, Małgorzata, była natomiast jedynym dzieckiem możnowładcy wielkopolskiego Wincentego Świdwy z Szamotuł herbu Nałęcz (syna Sędziwoja Świdwy z Szamotuł, wojewody poznańskiego) i bliżej nieznanej Anny ${ }^{15}$. Wincenty od młodych lat związany był z dworem króla Wła-

M. ČAPSKÝ: Vévoda Přemek Opavský..., s. 56-59, 70-71; M. STARÝ: „.. pojav k svatému manželství jich sestry dceru“. Marginálie ke genealogii slezských knižat a k osudưm Krnovska na přelomu 15. a 16. Století. „Časopis Matice moravské“ 2018, R. 137, č. 1, s. 57-86; TenżE: Sňatkové strategie opavských Přemyslovců. „Acta historica Universitatis Silesianae Opaviensis" 2012, T. 5, s. 69-82.

12 E. Zivier: Geschichte des Fürstentums Pless. Bd. 1. Kattowitz 1906, s. 88; A. Weltzel: Historia miasta Żory na Górnym Śląku. Żory 1997 (przekład polski na podstawie: TenżE: Geschichte der Stadt Sohrau in Oberschlesien. Sohrau 1888), s. 42 (tu jednak pod błędną datą 10 września 1427 r.). Dokument dotyczył sprzedaży przez księżną Helenę jej dworu w Wiśle Polskiej Andrzejowi Jałowcowi ze Strumienia za 6 grzywien. Pozostałe dokumenty wystawione przez Helenę z synami zestawia J. SPERka: Pszczyna i ziemia pszczyńska..., s. 92-93.

13 Pierwszy znany dokument wystawiony wspólnie przez Mikołaja i Wacława pochodzi z 27 października 1428 r. - CDSil, T. 6, s. 51-52, nr 175.

${ }^{14}$ Centrum Informacji Naukowej i Biblioteka Akademicka w Katowicach, Copiarius monasteri ad S. Venceslaum. Diplomatarius Silesiacarum (dalej: CMV) — mikrofilm, sygn. Mf. 166, 1-2 (oryginał w Bibliotece Narodowej w Pradze, sygn. 6 XVI 8), s. 605v-607 = CDSil, T. 6, s. 59-61, nr 195 (regest) = LBS, T. 2, s. 394 (regest). Szczegółowo na temat podziału księstwa zob. J. SPerka: Do 1532 roku. W: Rybnik. Dzieje miasta i jego dzielnic. T. 1. Red. Z. HojkA, B. KLOCH. Rybnik 2017, s. 141-142.

15 A. GĄSIOROwSKI: Szamotulski Wincenty Świdwa. W: Wielkopolski słownik biograficzny. Warszawa-Poznań 1981, s. 729; T. JureK: Szamotulski Wincenty Świdwa, h. Nałęcz 
dysława Jagiełły. Uczestniczył w soborze w Konstancji, wtedy też zwiedził kraje europejskie, docierając nawet do Hiszpanii, gdzie został pasowany na rycerza. W następnych latach uczestniczył w licznych misjach dyplomatycznych i wyprawach wojennych. Piastował kolejno urzędy: podczaszego kaliskiego (1414 - 1423), kasztelana międzyrzeckiego (1423 - 1444), starosty wschowskiego (1424-1427) i generalnego Rusi (1431-1439/1440). Od 1440 roku towarzyszył królowi Władysławowi III na Węgrzech. Zmarł nagle w czasie marszu armii królewskiej przeciw Turkom w Bułgarii, w nocy z 20 na 21 października $1444 \mathrm{roku}^{16}$. Ojciec Małgorzaty przez wiele lat pozostawał $\mathrm{w}$ niedziale majątkowym z bratem Dobrogostem, który zarządzał dobrami rodzinnymi zgrupowanymi wokół Szamotuł i Czempinia w Wielkopolsce; do podziału doszło dopiero w końcu lat 20., ale nie znamy jego szczegółów ${ }^{17}$. Prócz dóbr rodowych Wincenty z Szamotuł zgromadził liczne zapisy na dobrach królewskich, które za zasługi otrzymał od Władysława Jagiełły i Władysława III; większość z nich utrzymał do końca życia. W 1436 roku, będąc jeszcze starostą ruskim, otrzymał od króla - za nieznaną kwotę pieniędzy — Jaworów z przynależnościami w dystrykcie gródeckim w ziemi lwowskiej. Klucz ten składał się wtedy z miasta Jaworowa oraz wsi: Olszanica, Załuże, Jażów, wraz z łąkami Brzyska i Jagielnica ${ }^{18}$. Wincenty miał też miasto Tyśmienicę w ziemi halickiej,

(zm. 1444). W: PSB, T. 46, s. 586; W. BrZEZIŃski: Koligacje małżeńskie możnowładztwa wielkopolskiego w drugiej połowie XIV i pierwszej połowie XV wieku. Wrocław 2012, s. 161.

16 T. Jurek: Szamotulski Wincenty..., s. 584-587; A. GĄSIORowski: Szamotulski Wincenty..., s. 728-729; UrzWp, nr 133, 309, 644, s. 115, 135, 176; UrzRus, nr 1162 (tu błędna data początkowa sprawowania urzędu); Słownik historyczno-geograficzny województwa poznańskiego w średniowieczu. Cz. 1-4. Oprac. A. Gąsiorowski, T. Jurek, G. Rutkowska, P. Dembiński, K. Górska-Golaska, I. Skierska. Poznań 1982-2008 (dalej: SHGPoz) Cz. 4, s. 786-788, 801, 805. Pamięć Wincentego uczcił Marcin ze Słupcy wierszowanym epitafium. Dowiadujemy się z niego m.in. o niechęci Szamotulskiego do Niemiec, pasowaniu go na rycerza w Hiszpanii, walkach z Tatarami - A. BRÜCKNER: Średniowieczna poezya lacińska w Polsce. Kraków 1892, s. 25-28 („Rozprawy Akademii Umiejętności. Wydział Filologiczny" 1892, T. 16, s. 328-331). Na temat epitafium zob. także: J. NowaK-DŁużewSKI: Okolicznościowa poezja polityczna w Polsce. Średniowiecze. Warszawa 1963, s. 72-73; K. Weyssenhof-BrożKowa: Marcin ze Stupcy - poeta polskiego prerenesansu. „Eos” 1975, T. 63, s. 155-162; TAż: Marcin ze Stupcy. W: PSB, T. 19, s. 573; T. MichaŁowsKa: Literatura polskiego średniowiecza. Warszawa 2011, s. 871; TAż: Średniowiecze. Warszawa 2002, s. 693.

17 Z. GóRCZAK: Rozwój majątków możnowładztwa wielkopolskiego w drugiej połowie XV i początkach XVI wieku. Studium z dziejów wielkiej własności ziemskiej. Poznań 2007, s. 363; T. JuREK: Szamotulski Wincenty..., s. 586. O podziale między braćmi dowiadujemy się z zapisek sądowych dokumentujących rozliczenia Szamotulskich, do których doszło 1 lutego 1445 r. — zob. dalej.

${ }^{18}$ Dokumenty zastawne wystawione przez króla Władysława III, a dotyczące klucza jaworowskiego, nie zachowały się. Dowiadujemy się o nich z dokumentu króla Kazimierza Jagiellończyka z 1456 r. dla Piotra z Szamotuł, któremu monarcha sprzedał wymienione dobra na wyderkaf. Wtedy wspomniano, że zapis 600 grzywien posiadał wcześniej Wincenty, który to zapis teraz, po wykupieniu tenuty przez Piotra z Szamotuł, został skasowany - AGZ, T. 2, 
którą otrzymał może jeszcze od króla Władysława Jagiełły w nagrodę za walki z Tatarami ${ }^{19}$. Na Rusi posiadał także zapis 1700 grzywien na Szczerzecu, który jednak w 1441 roku władca wykupił. Monarcha zapisał mu również 210 grzywien i 400 florenów na Śremie w Wielkopolsce, ale w 1442 roku zastaw ten wykupiony został przez Michała Lasockiego ${ }^{20}$. W trakcie służby na Węgrzech za zasługi, w tym przyprowadzenie oddziałów zbrojnych, otrzymał od króla w 1441 i 1443 roku trzy pokaźne zapisy na poradlnym z Wielkopolski, co dało ogromną sumę 10000 grzywien ${ }^{21}$. Po śmierci Wincentego z Szamotuł jego córka stała się jedyną — wyłączając dożywotnie dobra winne i posagowe jej matki Anny — dziedziczką tego potężnego majątku.

Małgorzata Szamotulska, zanim wyszła za Wacława raciborskiego, była krótko żoną księcia Kazimierza II mazowieckiego i bełskiego. W literaturze historycznej przyjęto, opierając się na przekazie Jana Długosza, że związek małżeński został zawarty 26 czerwca 1442 roku w Turobinie (ziemia chełmska), w siedzibie Dobrogosta z Szamotuł, stryja panny młodej. Małżeństwo, jak się okazało - bezdzietne, przetrwało tylko trzy miesiące, przerwane zostało bowiem przez niespodziewaną śmierć księcia Kazimierza 16 września ${ }^{22}$. Ostatnio Janusz Grabowski zaproponował przesunięcie daty ślubu z 26 czerwca na 26 sierpnia $^{23}$. Korekta wynikała z tego, że Długosz, podając datę 26 czerwca (pod błędnym rokiem 1446), nadmieniał, że była to niedziela, a faktycznie 26 czerwca 1446 roku przypadał we wtorek. Wspomniany historyk zauważył jednak, że sprzeczność pomiędzy miesiącem a dniem tygodnia zniknęłaby, gdyby przyjąć, że ślub odbył się 26 sierpnia, który w 1442 roku przypadał w niedzielę. Sugerował, że podczas kopiowania tekstu mogło dojść do pominięcia dwóch „laseczek” określających miesiąc (VI - VIII). Poprawka ta jest jednak nie do utrzymania. Po pierwsze, w epitafium dla Wincentego z Szamotuł pióra Marcina ze Słupcy mamy wzmiankę, że małżeństwo jego córki Małgorzaty z księciem Kazimierzem trwało tylko trzy miesiące, przerwane

nr 85; J. SzyszKa: Formowanie się dóbr monarszych w ziemi lwowskiej od połowy XIV do początku XVI wieku. Kraków 2016, s. 290.

19 A. BrüCKner: Średniowieczna poezya..., s. 26; T. Jurek: Szamotulski Wincenty..., s. 585 .

${ }^{20}$ ZDM, Cz. 8, nr 2332 (pieniądze za Szczerzec miał wypłacić do 6 grudnia; gdyby się z tego nie wywiązał, miał dać wwiązanie do Śremu i Szadka). O wykupieniu Śremu przez Lasockiego zob. Inventarium, s. 283; A. GĄSIOROwSKI: Starostowie wielkopolskich miast królewskich $w$ dobie jagiellońskiej. Warszawa-Poznań 1981, s. 64.

${ }^{21} \mathrm{KDW}, \mathrm{T} .10$, nr 1547 (2 czerwca 1441 r. — 4000 florenów), 1618 (26 czerwca 1443 r. — 4000 florenów), 1623 (26 lipca 1443 r. - 2000 florenów); M. SePiaŁ: Zastaw na dobrach ziemskich $i$ dochodach królewskich $w$ okresie panowania Władysława III Warneńczyka na Wegrzech (1440-1444). W: ZNUJ, Nr 1219. Prace historyczne, z. 125. Kraków 1998, s. 37; Z. Górczak: Rozwój majątków..., s. 370.

22 Annales, lib. 12 [2003], s. 37 = Roczniki, ks. 12 [2004], s. 40; O. BALzer: Genealogia Piastów. Kraków 1895, s. 505; K. JAsińsKI: Rodowód Piastów mazowieckich..., s. 128-130.

23 J. Grabowski: Genealogia Piastów mazowieckich..., s. 466-467. 
przez niespodziewaną śmierć małżonka, co odpowiadałoby przekazowi Długosza (od czerwca do września) ${ }^{24}$. Po drugie, w księgach sądowych lwowskich z 22 czerwca i 6 lipca 1442 roku zachowały się informacje, że w rozpatrywanych wtedy sprawach Steczka z Głuchowic świadkowie nie mogli się stawić, ponieważ w tym czasie byli albo na Węgrzech przy królu, albo na uczcie weselnej księcia Kazimierza w Turobinie ${ }^{25}$. Daty te pokrywają się z informacjami Długosza o weselu, które miało odbyć się w końcu czerwca.

Pierwsza informacja dotycząca zawarcia małżeństwa między księciem Wacławem raciborskim a Małgorzatą Szamotulską pochodzi z 19 stycznia 1445 roku, kiedy książę zapisał wiano swojej żonie (o tym szczegółowo dalej) ${ }^{26}$. Historycy, którzy podejmowali problem tego mariażu, nie starali się jednak uściślić daty jego zawarcia, zadowalając się stwierdzeniem, że było to: przed 12 stycznia 1445 roku (to akurat wynikało ze złego rozwiązania daty wystawienia dokumentu), przed 19 stycznia 1445 roku, albo przesuwali je na 1440 lub 1443/1444 $\operatorname{rok}^{27}$.

Czas zawarcia związku można jednak doprecyzować, posiłkując się informacjami zawartymi $\mathrm{w}$ wierszowanym epitafium dla Wincentego z Szamotuł autorstwa Marcina ze Słupcy ${ }^{28}$. Wspomniana jest tam żona zmarłego, Anna, oraz - bezimiennie - córka, której mężem był książę Kazimierz. Marcin ze Słupcy nie wymienił jednak drugiego męża Małgorzaty, Wacława, księcia raciborskiego, co wskazuje, że kiedy pisał epitafium, małżeństwo to nie było jeszcze zawarte, ponieważ $\mathrm{w}$ innym przypadku z pewnością taką informację by zamieścił. Niewątpliwie Marcin ze Słupcy napisał epitafium po sprowadzeniu zwłok Wincentego do kraju (ewentualnie po dotarciu sprawdzonych informacji o tym zdarzeniu). Biorąc pod uwagę znaczną odległość dzielącą Wielkopolskę

24 A. BRÜCKNER: Średniowieczna poezya..., s. 27 (Preterea nata alto procata marito; Nomine si queras, dux Casimirus errat; Sed mors heu temera cabiat presidem milecida; Et tribus ante quater mensibus occubuit).

${ }_{25}$ AGZ, T. 14, $\mathrm{nr} 439$ (cum Duce Kazymyro in Convivio), 446 (in nupciis in Thurobyn cum duce Kazymiro).

${ }^{26}$ CDSil, T. 2, s. XXIV-XXVI.

27 H. Grotefend: Stammtafeln der Schlesischen Fürsten bis zum Jahre 1740. Breslau 1889, s. 21, 58, tab. 12 (przed 12 stycznia 1445 r.); O. BAlzer: Genealogia Piastów..., s. 505506 (na krótko przed 19 stycznia 1445 r.); G.P.A. Hausdorf: Die Piasten Schlesiens. Breslau 1933, s. 172 (tu tylko informacja, że zapisał jej dożywocie 19 stycznia 1445 r.); F. Kopetzky: Zur Geschichte und Genealogie der Přemyslidischen Herzoge von Troppau. „Archiv für österreichische Geschichte“ 1869, Bd. 41, s. 88 (tu tylko podany 1445 r.); L. Neustadt: Beiträge zur Genealogie schlesischer Fürsten. ZVGAS 1888, Bd. 22, s. 229 (tu jedynie data śmierci Małgorzaty); W. DworzaczeK: Genealogia. T. 2. Warszawa 1959, tab. 11 (przed 12 stycznia 1445 r.); W. Korta: Matgorzata z Szamotut (zm. 1464). W: PSB, T. 19, s. 443 (przed 19 stycznia 1445 r.); F. СносноlatÝ: Genealogie opavských Přemyslovců..., s. 151 (nie podał daty zawarcia małżeństwa, jednak narodziny syna Jana z tegoż związku datował na ok. 1440 r.); W. BrzezińsKi: Koligacje małżeńskie..., s. 186 (datę zawarcia małżeństwa datował na 1443/1444 r.).

28 A. BRÜCKNER: Średniowieczna poezya..., s. 25-28. 
od Bułgarii (ok. $1700 \mathrm{~km}$ ) i czas potrzebny na jej pokonanie, czyli ok. 6-7 tygodni, epitafium powstało najpewniej w grudniu $1444 \mathrm{roku}^{29}$. Zatem — idąc tym tokiem rozumowania — ślub Małgorzaty i Wacława musiałby się odbyć najwcześniej w samej końcówce grudnia 1444 roku, po zakończeniu adwentu (i krótkiej żałoby), a pierwszy możliwy termin to święta Bożego Narodzenia albo, co wydaje się bardziej prawdopodobne, początek stycznia 1445 roku (może w Święto Trzech Króli?). Koresponduje zresztą z tym zapis wiana dokonany przez księcia Wacława 19 stycznia tego roku, a więc wkrótce po zaślubinach.

Małżeństwo Małgorzaty Szamotulskiej z Wacławem raciborskim najpewniej zaaranżowała jego siostra Małgorzata, w tym czasie wdowa po księciu mazowieckim Siemowicie V, bracie Kazimierza II bełskiego, pierwszego męża Szamotulskiej ${ }^{30}$. Księżna była bowiem osobą najlepiej zorientowaną w sytuacji, znała przecież dobrze swoją szwagierkę pod każdym względem. Dla Wacława, władcy niewielkiego księstwa, wysoki posag przyszłej małżonki, wywodzącej się z jednej z najważniejszych rodzin Korony Polskiej, z pewnością był dużą pokusą. $\mathrm{W}$ dodatku, ten atut materialny łączył się zapewne $\mathrm{z}$ walorami osobistymi Małgorzaty, urodą i wdziękiem, które — jak można się domyślać — odziedziczyła po ojcu ${ }^{31}$.

Należy przypuszczać, że uroczystości weselne odbyły się w stolicy księstwa, w Raciborzu. Tam też 19 stycznia 1445 roku książę Wacław zapisał swej żonie Małgorzacie wiano w wysokości 6000 grzywien groszy praskich, a sumę zabezpieczył na dobrach leżących w dystrykcie raciborskim. W ich skład wchodziły: zamek i miasto Racibórz, Nowe Miasto, przedmieścia, dwa młyny na Odrze, jeden pod zamkiem, drugi w mieście (z wyjątkiem młyna na rzece Psinie, który rezerwował dla siebie i swoich spadkobierców), folwarki położone na Goli32, w Miedonii, w Ocicach, w Bojanowie oraz wsie, też wszystkie położone na Goli, a mianowicie: Stara Wieś, Nowe Ogrody, Proszo-

${ }^{29} \mathrm{~W}$ literaturze historycznej powstanie epitafium datowano ogólnie na 1445 r. albo na 1446 r. — zob. tamże, s. 22; J. Nowak-DŁużewski: Okolicznościowa poezja..., s. 72 -73; K. Weyssenhof-Brożkowa: Marcin ze Stupcy — poeta polskiego prerenesansu..., s. 155162; TAż: Marcin ze Stupcy..., s. 573; T. MichaŁowska: Literatura polskiego średniowiecza..., s. 871; TAŻ: Średniowiecze..., s. 693.

${ }^{30}$ Małgorzata raciborska poślubiła Siemowita V mazowieckiego w 2. poł. lat 30. XV w. Po śmierci męża (16 lub 17 lutego 1442 r.) księżna władała ziemią gostynińską, na której miała zabezpieczoną oprawę wdowią; zmarła 5 lipca 1459 r. - K. JAsıŃsKI: Rodowód Piastów mazowieckich..., s. 110-111; J. Grabowski: Genealogia Piastów mazowieckich..., s. 462-464.

${ }^{31} \mathrm{O}$ walorach osobistych, dobrych manierach i urodzie Wincentego z Szamotuł informują Marcin ze Słupcy w epitafium (A. BRÜCKNER: Średniowieczna poezya..., s. 26) oraz J. Długosz (Annales, lib 11 et 12 [2001], s. 240 = Roczniki, ks. 11 i 12 [2004], s. 269).

${ }^{32}$ Gola (dawniej: ziemia plemienia Golężyców), bezleśna kraina, golizna, obszar rolniczy rozciągający się na pograniczu polsko-morawskim; np. w dokumencie księcia Przemysława raciborskiego z 1306 r. (9 kwietnia) określano, że wieś Ottona położona jest na Goli, w pobliżu Raciborza naprzeciw Opawy (villam dictam Ottonis, sitas in Gola, prope Rathybor versus Opaviam) - CDSil, T. 2, s. 118, nr 11. 
wiec, Szeroka Ulica, Miedonia, Brzeźnica, Rudnik, Szonowice, Pawłów, Maków, Janowice, Ocice, Lekartow, Bojanów, Bieńkowice, Studzienna, Gamów Niemiecki, Krawarz (dziś: Krowiarki), Podlesie ${ }^{33}$. Dalej cło w Raciborzu oraz prawo patronatu w tamtejszych kościołach i prebendach, dwa stawy, jeden położony przy Odrze, pod górą, która znajdowała się za ujściem do rzeki (właściwie strugi) Łęgoń, drugi w Markowicach (dziś: dzielnica Raciborza), a także wszystkich rybaków łowiących na Odrze, którzy dostarczają ryby do zamku. Z wymienionych dóbr i dochodów księżna miała prawo korzystać dożywotnio po śmierci męża. Gdyby jednak jego sukcesorzy chcieli je przejąć, musieliby wypłacić wdowie wspomnianą sumę 6000 grzywien. Na zapis wiana wyrazili zgodę ziemianie księstwa, z których na dokumencie jako świadków wpisano: rycerza Mikołaja Marszałka z Frydka, chorążego Andrzeja z Tworkowa, Burcharda z Rzuchowa, Mikosza z Pilchowic, Tomasza ze Strzybnika, Pietrasza z Pielgrzymowic, Mikołaja Golego z Ponięcic i Mikołaja Wołczkowica, notariusza książęcego ${ }^{34}$.

Wkrótce po uroczystościach weselnych para książęca udała się do Wielkopolski, aby uregulować sprawy majątkowe, przede wszystkim rodzinne, ale nie brakowało też problemów sąsiedzkich ${ }^{35}$. 1 lutego 1445 roku w Szamotułach w obecności przybyłego tam starosty generalnego Wielkopolski i jednocześnie namiestnika króla w tej dzielnicy Wojciecha Malskiego — doszło do podziału majątku, wzajemnych rozliczeń i transakcji między Szamotulskimi. Stronami byli: Małgorzata z mężem Wacławem raciborskim, jej matka Anna, wdowa po Wincentym, stryj Małgorzaty Dobrogost Świdwa z Szamotuł, kasztelan poznański, z synami Piotrem i Janem ${ }^{36}$. Zawiły podział majątku Szamotulskich wpisany do ksiąg sądowych analizowany był dotąd przez kilku historyków ${ }^{37}$.

${ }^{33} \mathrm{Z}$ wymienionych osad w granicach dzisiejszego Raciborza znajdują się: Nowe Miasto, Stara Wieś, Nowe Ogrody (dziś: Nowe Zagrody), Proszowiec, Szeroka Ulica (później Bronki, dziś: ulica księdza Józefa Londzina), Miedonia, Ocice i Studzienna.

${ }^{34}$ CDSil, T. 2, s. XXIV-XXVI. Dokument znamy z transumptu Piotra z Szamotuł, kasztelana poznańskiego i starosty wielkopolskiego, z 20 września 1463 r., wystawionego w Poznaniu. W transumpcie znajdują się informacja, że oryginalny dokument zapisu wiana przechowywał Dobrogost z Szamotuł, stryj Małgorzaty, oraz dokładny opis pieczęci księcia Wacława, odciśniętej w czerwonym wosku, którą był opatrzony dokument.

35 Znaczna odległość Raciborza od Wielkopolski powodowała, że Małgorzata, pozywana przez swoich sąsiadów w sprawach o dobra, nie była w stanie wywiązywać się z obowiązku uczestniczenia w rozprawach. Widać to np. w 1445 r., kiedy pozwana przez Dziersława z Rozwarowa ze wsi Radzyny, Baworowo, Popowo Nowe i Piotrkowo została skazana na zapłacenie sądowi 8 skojców kary z powodu niestawienia się na rozprawy — SHGPoz, Cz. 1, s. 21; Cz. 3, s. 676,784 .

${ }^{36}$ AP Poznań, Księga grodzka poznańska (dalej: GPoz) 2, k. 89-90, 99v; Z. GóRCZAK: Rozwój majątków..., s. 363; SHGPoz, Cz. 4, s. 789, 793, 804, przyp. 26; T. JureK: Szamotulski Wincenty..., s. 585.

37 Z. GórczaK: Rozwój majątków..., s. 363-366; W. Brzeziński: Koligacje malżeńskie..., s. 153, 163; SHGPoz, Cz. 1, s. 21; Cz. 3, s. 676, 784; Cz. 4, s. 789, 793, 804. 
Ci jednak nie konfrontowali wzajemnych ustaleń, co spowodowało, że w literaturze można zaobserwować dość rozbieżne tezy na ten temat, a co za tym idzie, problem wymaga ponownej analizy.

W przypadku dóbr wielkopolskich Małgorzata Szamotulska miała prawo do tych, które otrzymał jej ojciec w podziale przeprowadzonym z bratem Dobrogostem. Analizując dzieje poszczególnych osad — ponieważ brakuje szczegółowego dokumentu podziału - można wnioskować, że z dóbr rodzinnych przypadły jej: połowa miasta Szamotuły z pobliskimi wsiami Kępą i Nową Wsią oraz Stare Miasto (dziś: Stare Szamotuły), dalej klucz czempiński, na który składały się miasto Czempiń i wsie: Borówko (dziś: Stare Borówko), Piechinino (dziś: Piechanin), Tarnowo (dziś: Stare Tarnowo) oraz połowa Borowa, klucz stobnicki, w skład którego wchodziły miasto Stobnica oraz wsie: Baworowo (dziś: Baborowo), Brączewo, Gąsawy, Jaryszewo, Pamiątkowo, Piotrkowo (dziś: Piotrówko), Podlesie, Popówko, Radzyny (dawniej: Radzin), Sycyn (dawniej: Sycyno) i połowa Bądlina (dziś: Bąblin), a także leżące w znacznym oddaleniu od tych dóbr w powiecie kcyńskim Grocholin (ojcowizna jej matki Anny) i Gromadno. W sumie dawało to 3 miasta i $20 \mathrm{wsi}^{38}$. Małgorzata musiała jednak uwzględnić prawa swej matki Anny do jej dóbr rodowych oraz tych, na których ta miała zapisane posag i wiano. Zanim nastąpiły wzajemne rozliczenia, Małgorzata (1 lutego 1445) - z tytułu kontraktu małżeńskiego zrezygnowała na rzecz męża z 1/3 dóbr odziedziczonych po ojcu w Wielkopolsce, co spowodowało, że ten stał się ich pełnoprawnym właścicielem ${ }^{39}$. Następnie część przypadłych jej w podziale dóbr, a mianowicie połowę miasta Szamotuły z dworem i fortalicjum oraz wsie Kępa i Nowa Wieś, przekazała stryjowi Dobrogostowi oraz jego synom Janowi i Piotrowi. Przyczyną oddania był zapewne fakt, że na tych wsiach ciążył niewykupiony zastaw 410 grzywien zaciągniętych przez jej ojca od różnych właścicieli, który spłacił Dobrogost $^{40}$. Z kolei stryj Dobrogost przekazał Małgorzacie wieś Stare Miasto, którą jej ojciec trzymał z nim w działach braterskich ${ }^{41}$. Następnie księżna — wraz z mężem - wyraziła zgodę, aby jej matka Anna (pisząca się wtedy z Turostowa) sprzedała wsie Grocholin i Gromadno za 2000 grzywien Dobrogostowi z Szamotu1 ${ }^{42}$. Tego samego dnia (1 lutego) Małgorzata i Wacław sprzedali za

${ }^{38}$ Z. GóRCZAK: Rozwój majątków..., s. 363-364 (autor podaje, że były to 3 miasta i 21 wsi, ale dodaje jeszcze Turostowo, które było dziedzictwem matki i Wiry; Małgorzata miała do nich prawo, ale dopiero po śmierci matki); SHGPoz, Cz. 1, s. 21; Cz. 3, s. 676, 784.

${ }^{39}$ GPoz 2, k. 89v—90; W. Brzezıński: Koligacje matżeńskie..., s. 163; SHGPoz, Cz. 4, s. 793.

${ }^{40}$ GPoz 2, k. 89-90; Z. GórczaK: Rozwój majątków..., s. 364, 371; SHGPoz, Cz. 2, s. 163; Cz. 3, s. 322; Cz. 4, s. 789, 805, przyp. 33.

${ }^{41}$ GPoz 2, k. 99v; SHGPoz, Cz. 4, s. 793.

${ }^{42}$ GPoz 2, k. 89-89v; W. BrzeziŃski: Koligacje matżeńskie..., s. 152-153; SHGPoz, Cz. 4, s. 787. Transakcja nie doszła jednak do skutku, ponieważ kilka miesięcy później 22 maja 1445 r. - Anna sprzedała Gromadno wraz z Grocholinem Mikołajowi z Oporowa 
taką samą sumę, czyli 2000 grzywien, matce Annie 4 wsie: Stare Miasto, Baworowo, Piotrkowo i Radzyny. Jednocześnie uczyniono zastrzeżenie, że gdyby Małgorzata zmarła bezpotomnie, to pieniądze za te wsie miałyby przypaść Annie i jej spadkobiercom ${ }^{43}$.

Klucz czempiński Małgorzata utrzymała tylko przez rok, by 21 marca 1446 roku sprzedać miasto Czempiń z wsiami Piechinino, Tarnowo, Borówko oraz połowę Borowa za 6000 florenów Janowi Bnińskiemu. Transakcji dokonała za zgodą stryja Dobrogosta z Szamotuł i wuja Trojana z Łekna (h. Pałuka), sędziego kaliskiego ${ }^{44}$. Odstąpienie dóbr odbyło się jednak z opóźnieniem, gdyż księżna do 24 czerwca nie wywiązała się z umowy i z tego tytułu — jak jeszcze zeznał w tym roku Dobrogost z Szamotuł, który pewnie zarządzał dobrami w imieniu Małgorzaty — braciom Bnińskim, Janowi, Piotrowi i Wojciechowi, należało się odszkodowanie w wysokości 400 grzywien $^{45}$.

Po tej transakcji Małgorzacie i jej mężowi zostały jedynie prawa spadkowe do części klucza stobnickiego, ale dopiero po śmierci matki Anny, która miała na nim zapisane sumy posagowe i wienne. Anna rezydowała w Stobnicy do końca życia; zmarła po 5 czerwca 1461 roku, kiedy po raz ostatni została odnotowana w źródłach jako osoba żyjąca ${ }^{46}$.

W wyniku tych skomplikowanych transakcji księżna Małgorzata ze sprzedaży dóbr wielkopolskich uzyskała — jak można obliczyć — 2000 grzywien i 6000 florenów.

Małgorzata Szamotulska odziedziczyła po ojcu także wszystkie królewszczyzny na Rusi, które skupione były wokół Jaworowa w dystrykcie gródeckim w ziemi lwowskiej i w Tyśmienicy w ziemi halickiej. Niestety niewielka liczba dokumentów dotyczących losów tych dóbr, w tym również niekompletność aktów sądowych lwowskich (zachowały się tylko akta grodzkie) i halic-

w zamian za wieś Modrzew (powiat piotrkowski) i dopłatę 2000 grzywien — GPoz 2, s. 104v; W. BrzezińsKi: Koligacje matżeńskie..., s. 153. Z. GóRCZAK (Rozwój majątków..., s. 371) błędnie podaje, że wymienione wsie Małgorzata i Wacław odstąpili wcześniej matce Annie za 2000 grzywien.

${ }^{43}$ GPoz 2, k. 90; Z. GórczaK: Rozwój majątków..., s. 371; W. Brzeziński: Koligacje malżeńskie..., s. 153; SHGPoz, Cz. 1, s. 20; Cz. 4, s. 32.

${ }^{44}$ GPoz 2, s. 450; Z. Cieplucha: Z przeszłości ziemi kościańskiej. Kościan 1929, s. 123, 138; SHGPoz, Cz. 1, s. 91 (Borowno), 303 (Czempiń); Z. GórczaK: Rozwój majątków..., s. 50, 372. Błędną datę transakcji - $1447 \mathrm{r}$. — z powołaniem się na tę samą zapiskę podaje W. BRzEzIŃski: Koligacje małżeńskie..., s. 160-161.

${ }^{45}$ AP Poznań, Księga ziemska poznańska (dalej: ZPoz) 15, k. 215v; SHGPoz, Cz. 1, s. 303 (Czempiń); Z. GórCZAK: Rozwój majątków..., s. 50, 372.

${ }^{46}$ AP Poznań, Księga grodzka gnieźnieńska (dalej: GGn) 2, k. 1ov-2. Trafnie datował śmierć Anny - po 5 czerwca 1461 r. a przed 3 grudnia 1465 r. - W. Brzezıński: Koligacje matżeńskie..., s. 161. Natomiast Z. GóRCZAK (Rozwój majątków..., s. 372, przyp. 135) oraz Paweł Dembiński (SHGPoz, Cz. 4, s. 32), w związku z tym, że błędnie utożsamili Annę raciborską z Anną Szamotulską z zapisek z 3 grudnia 1465 r. (ZPoz 18, k. 102-102v, 109v), niesłusznie przesuwali jej śmierć po tej ostatniej dacie; na ten temat szczegółowo zob. dalej. 
kich (zachowały się tylko akta ziemskie) z interesującego nas okresu, uniemożliwia szczegółowe odtworzenie procesu przejęcia dóbr, zarządu nimi oraz ich utraty przez księżną Małgorzatę i księcia Wacława raciborskiego ${ }^{47}$.

Jak wspomniałem, ojciec Małgorzaty, Wincenty Świdwa z Szamotuł, otrzymał od króla Władysława III kilka zapisów na tenucie jaworowskiej. Dokumenty zastawne niestety nie zachowały się, ale dowiadujemy się o nich z dokumentu króla Kazimierza Jagiellończyka z 1456 roku dla Piotra z Szamotuł, któremu monarcha sprzedał te dobra ${ }^{48}$. Jest tam informacja, że w 1436 roku Wincenty z Szamotuł otrzymał w zastaw od króla Władysława III miasto Jaworów, wsie Olszanica, Załuże, Jażów oraz łąki Brzyska i Jagielnica ${ }^{49}$. Szamotulski miał także osobne zapisy na innych wsiach, które leżały w pobliżu Jaworowa - o nich też dowiadujemy się z późniejszych źródeł — i następnie weszły do skonsolidowanej tenuty, a mianowicie na: Tuczapach, Zbadyniu, Krechowie i Obroszynie ${ }^{50}$.

Znaczne oddalenie księstwa raciborskiego od dóbr ruskich, które przejęła Małgorzata, z pewnością utrudniało zarządzanie nimi, ale absolutnie nie można powiedzieć, że księżna się nimi nie interesowała - wręcz przeciwnie. Wszystkimi dobrami — jaworowskimi i tyśmienickimi — administrował w jej imieniu Wojciech piszący się później z Buczniowa w ziemi halickiej, określany w latach 1446-1449 jako jej zarządca („officialis”) ${ }^{51}$. Pochodził z Wielkopolski, gdzie pierwotnie pełnił funkcję pisarza w sądzie ziemskim pyzdrskim, a na Ruś został najpewniej sprowadzony jeszcze przez Wincentego z Szamotu1 ${ }^{52}$. Musiał się szybko wzbogacić, skoro w 1449/1450 roku wziął w zastaw od pary książęcej dobra jaworowskie; od 1450 roku (3 lipca) przed sądem nazywany był już tenutariuszem księcia (,tenurarius domini Venceslai Ducis in Jaworow”) lub księżnej (,tenutarius de Iaworow preclare Margarethe Ducisse Ratibor[ienssis]") ${ }^{53}$. Dobra te zostały wykupione najpóźniej przed 20 lutego 1454 roku, kiedy książę Wacław fundował w Jaworowie kościół parafialny (o czym dalej) $)^{54}$. W 1451 roku Wojciech przejął na podobnej zasadzie wsie

47 AGZ, T. 12, s. XIV; T. 14, s. V-VI.

48 Tamże, T. 2, nr 85.

49 Tamże; J. Szyszka: Formowanie się dóbr monarszych..., s. 290.

50 J. SzYSZKa: Formowanie się dóbr monarszych..., s. 243, 291, 421, 433.

${ }^{51} 16$ grudnia 1446 r. przed sądem grodzkim lwowskim występował jako: Officialis bonorum in terra Russie illustrius domine Margarethe Ducisse preclari Ducis dom. Venceslai Rathiborien. Zeznał wtedy, że otrzymał 13,5 grzywny od Jana Czyrana z Czepowa, któremu pożyczył tę kwotę Wincenty z Szamotuł, ojciec Małgorzaty - AGZ, T. 14, nr 1835.

52 Tamże; Z. GórCZaK: Rozwój majątków..., s. 369.

53 AGZ, T. 14, nr 2343, 2355-2360, 2420-2424, 2430, 2440-2441; J. SZYsZKa: Formowanie się dóbr monarszych..., s. 292.

${ }^{54}$ AGZ, T. 5, nr 135 = S. TYLus: Fundacje kościołów parafialnych $w$ średniowiecznej archidiecezji lwowskiej. Lublin 1999, nr 18. Wojciech jako tenutariusz w Jaworowie ostatni raz wzmiankowany jest 20 marca 1451 r. - AGZ, T. 14, nr 2441. 
Tuczapy i Zbadyń, na których Małgorzata (a najpewniej już jej ojciec) miała zapisane od króla 320 grzywien. W tym samym roku (26 sierpnia 1451) wystarał się o zgodę Kazimierza Jagiellończyka na ten podzastaw za wspomnianą sumę ${ }^{55}$. Wymienione dwie wsie utrzymał zapewne do $1453 \mathrm{roku}^{56}$. Najpewniej także w 1451 roku - o czym dalej — został też tenutariuszem Tyśmienicy, gdyż tak określany jest we wspomnianym dokumencie królewskim dotyczącym Tuczap i Zbadynia ${ }^{57}$.

Zaangażowanie pary książęcej w kwestię dóbr ruskich widać najlepiej na przykładzie Jaworowa, który od 1454 roku nazywany był miastem. Historycy sugerują, że to $\mathrm{z}$ ich woli osada uzyskała prawa miejskie ${ }^{58}$. Niewątpliwie natomiast dzięki parze książęcej doszło w Jaworowie do fundacji kościoła parafialnego. Miało to miejsce w czasie jej pobytu w Krakowie 20 lutego 1454 roku w związku z uroczystościami weselnymi króla Kazimierza Jagiellończyka i Elżbiety Habsburżanki. Wtedy to książę Wacław raciborski, tytułując się dziedzicem Jaworowa, wystawił dokument fundacyjny dla tamtejszego kościoła parafialnego pw. Wniebowstąpienia Najświętszej Marii Panny i św. Barbary. Świątynię uposażył: dziesięciną małdratową ze wszystkich zbóż z młyna książęcego w Jaworowie stojącego nad rzeką Szkło, stawem na strumieniu Jaksza leżącym między wsiami Załuże i Stary Jażów, dwoma łanami w Jaworowie oraz łąką leżącą między tymi łanami a bagnem, dwoma ogrodami, a także dziesięciną snopową z ról książęcych we wsi Zbadyń i z innych wsi książęcych. Ponadto kościół miał mieć płacone przez 10 lat po 1 groszu kwartalnie od wszystkich osadników na prawie niemieckim, a następnie meszne, które wynosiło po 1 kłodzie żyta i owsa $\mathrm{z}$ łanu oraz 1 miarę soli kwartalnie z cła w Jaworowie. W momencie fundacji uposażenie przechodziło w posiadanie ówczesnego rektora kościoła, którym był Mikołaj z Gródka, wtedy kapelan książęcy. Akt fundacyjny został dokonany w obecności towarzyszących księciu dostojników raciborskich, a mianowicie: Bernarda z Wartnowa, Mikołaja zwanego Goly (Łysy) z Ponięcic, Mikosza z Pilchowic oraz Mikołaja, prepozyta z Raciborza ${ }^{59}$.

Całe to przedsięwzięcie musi dziwić w kontekście wydarzeń następnych kilkunastu dni, kiedy to tenuta jaworowska decyzją królewską przeszła w ręce

55 AGAD, Metryka Litewska, Dz. IV B., syg. 9 [Księga wpisów przywilejów na dobra w województwie ruskim przedkładanych podczas ,,rewizji listów” w 1563/1564], (dalej: Rewizja listów), k. 293v-294; Kartoteka osad ziemi lwowskiej w Pracowni Słownika Historyczno-Geograficznego Małopolski w Instytucie Historii PAN w Krakowie (Jaworów).

${ }_{56}$ Jeszcze w 1453 r. tytułowany był tenutariuszem Tuczap i Zbadynia; wtedy to Dobrogost z Szamotuł - poprzez swego pełnomocnika Mikołaja z Pyzdr, mieszczanina lwowskiego pozywał Wojciecha, tenutariusza w Zbadyniu i Tuczapach, o szkody w tych dobrach - AGZ, T. 14, nr 2769, 2771, 2787-2788.

57 Rewizja listów, k. 293v-294; Kartoteka osad ziemi lwowskiej... (Tuczapy, Zbadyń).

58 J. SZYSZKa: Formowanie się dóbr monarszych..., s. 191.

${ }_{59}$ AGZ, T. 5, nr 135 = S. Tylus: Fundacje..., nr 18. 
Piotra z Szamotuł, kasztelana poznańskiego, brata stryjecznego księżnej Małgorzaty. Dnia 7 marca 1454 roku w Krakowie król zapisał bowiem Piotrowi z Szamotuł 600 grzywien na Jaworowie i Środzie (w Wielkopolsce) z przyległościami. Przy tej okazji wspomniano w akcie o wcześniejszym dokumencie króla Władysława III dla Wincentego z Szamotuł z zapisem 600 grzywien na Jaworowie i Środzie. Jednak — jak stwierdzono dalej — po wykupieniu przez Piotra Szamotulskiego tych miast z przynależnymi wsiami od Małgorzaty, księżnej raciborskiej, dokumenty te zostały skasowane i złożone w kancelarii królewskiej ${ }^{60}$. Wynika $\mathrm{z}$ tego, że po 20 lutego (fundacja kościoła przez Wacława w Jaworowie) a przed 7 marca Piotr Szamotulski za zgodą króla wykupił tenutę jaworowską od Małgorzaty Szamotulskiej. Proces przejmowania poszczególnych wsi przeciągnął się jednak, gdyż jeszcze w 1456 roku Obroszyn był w posiadaniu Małgorzaty i Wacława ${ }^{61}$. Przed 1456 rokiem (13 lutego 1455) para książęca podzastawiła nawet Obroszyn Mikołajowi (Niklowi) z Rostkowic i Podhorców ${ }^{62}$. W tym roku, 1456, cała tenuta jaworowska wraz z Krechowem i Obroszynem przeszła w posiadanie Piotra z Szamotuł. Ze względu na brak odpowiednich dokumentów nie znamy kwoty wykupu dóbr jaworowskich. Janusz Szyszka na podstawie dokumentów wystawionych przez króla odnośnie do tych dóbr w 1454 i 1456 roku szacuje, że mogło to być 2420 grzywien $^{63}$. Ostatecznie Kazimierz Jagiellończyk w 1456 roku (22 listopada) sprzedał z prawem odkupu (na wyderkaf) Szamotulskiemu zastawione mu dobra jaworowskie za sumę 1300 grzywien i 1650 florenów ${ }^{64}$.

Inaczej potoczyły się losy dóbr tyśmienickich, chociaż finał był podobny. Tyśmienicę Wincenty z Szamotuł posiadał z nadania Władysława III albo jeszcze z łaski Władysława Jagiełły, i to najpewniej nie jako zastaw, tylko nadanie wieczyste ${ }^{65}$. W skład dóbr tyśmienickich, prócz miasta Tyśmienicy, wchodziło zapewne jeszcze 10 wsi, a mianowicie: Mikityńce, Wołczyniec, Podpieczary, Studzieniec, Pszeniczki, Łopianka, Chuzyn, Olszanica, Klubowce, Hułowce ${ }^{66}$.

${ }^{60}$ Rewizja listów, k. 294v-295v; J. Szyszka: Formowanie się dóbr monarszych..., s. $290-291$.

${ }^{61}$ Rewizja listów, k. 294v-295v; AGZ, T. 19, nr 2720; J. SzyszKa: Formowanie się dóbr monarszych..., s. 292.

${ }^{62}$ Wtedy to Nikel z Rostkowic ręczył za parę książęcą, Małgorzatę i Wacława, Grzegorzowi z Santoka, arcybiskupowi lwowskiemu, i zobowiązał się do dania mu wwiązania w swą tenutę Obroszyn w przypadku niedotrzymania poręki - AGZ, T. 19, nr 2720; J. SzYszza: Formowanie się dóbr monarszych..., s. 243-244.

${ }^{63}$ Rewizja listów, k. 294v—295v; J. SzyszKa: Formowanie się dóbr monarszych..., s. 291.

${ }^{64}$ Rewizja listów, k. 294v-295v; AGZ, T. 2, nr 85; J. SzyszKa: Formowanie się dóbr monarszych..., s. 291.

${ }_{65}$ Andrzej Szamotulski (syn Piotra), sprzedając dobra tyśmienickie w 1511 r., określił je jako dziedziczne (bona sua haereditaria) — MRPS, T. 4, nr 9886.

${ }^{66}$ Skład klucza tyśmienickiego poznajemy z dokumentu jego sprzedaży — za 6000 florenów - przez Andrzeja Szamotulskiego, wojewodę poznańskiego, braciom Paniowskim w 1511 r. 
Aktywność księżnej Małgorzaty odnośnie do tych dóbr zamyka się w okresie 30 października 1447 -4 stycznia 1454 roku. W tym czasie toczyła kilka spraw z sąsiadami, a mianowicie, przed sądem ziemskim halickim z Abrahamem Chochołowskim (1447-1448), a następnie ze Stefanem Bydłowskim (1448 - 1449); w obydwu przypadkach skończyło się odesłaniem spraw do rozpatrzenia przez wiec halicki ${ }^{67}$. Księżna miała też sprawy przed sądem grodzkim we Lwowie z Małgorzatą, wdową po Janie Doluskim (1448), i przed sądem ziemskim lwowskim z nieznanym pozwanym $(1454)^{68}$.

Dobrami tyśmienickimi w imieniu Małgorzaty i Wacława opiekowali się podobnie jak w przypadku dóbr jaworowskich - zarządcy tytułowani zamiennie oficjałami, prokuratorami czy wojewodami. Najpierw był to wspomniany już Wojciech, który administrował dobrami w latach 1447-144969. W 1449 roku zastąpił go Stanisław ${ }^{70}$, a kolejnym był Jan Nosz, który już wcześniej pełnił tę funkcję (1437-1438), a zarządzał ponownie dobrami w latach $1451-1453^{71}$. Natomiast w 1451 roku (26 sierpnia) Wojciech został określony w dokumencie królewskim jako tenutariusz Jaworowa i Tyśmienicy ${ }^{72}$. Jeśli nie jest to pomyłka, to wskazywałoby, że podobnie jak w przypadku Jaworowa dobra tyśmienickie dostały się w jego posiadanie jako zastaw od Małgorzaty Szamotulskiej.

Jednak już w 1449 roku prawa do Tyśmienicy — zapewne do jakiejś części — posiadał też stryj Małgorzaty Dobrogost z Szamotuł, kasztelan poznański, gdyż występował (1 stycznia) wspólnie z nią w sprawie przeciw Bydłowskiemu oraz pisał się z tego miasta ${ }^{73}$. Należy przypuszczać, że prawa nabył właśnie od Małgorzaty i Wacława. Ostatecznie klucz tyśmienicki przeszedł w ręce Szamotulskich, chociaż nie wiadomo, kiedy do tego doszło i na jakich warunkach. Orientacyjnie można wnioskować, że stało się to po 4 stycznia 1454 roku, kiedy Małgorzata po raz ostatni została odnotowana jako właścicielka dóbr, a przed 7 lutego 1457 roku, kiedy Piotr Szamotulski w aktach sądowych występował już jako pan Tyśmienicy ${ }^{74}$.

— tamże. Akt sprzedaży obejmował jeszcze trzy inne wsie: Uhorniki, Podłuże i Dubrowlany, ale - jak ustalił Z. GóRCZAK (Rozwój majątków..., s. 369) — zostały one dokupione przez Szamotulskich w 2. poł. XV w.

${ }^{67}$ AGZ, T. 12, nr 1823, 1852, 1877, 1950, 1973, 2072, 2111, 2189, 2252, 2283; Z. GóRCZAK (Rozwój majątków..., s. 373) błędnie podaje, że jej aktywność w sprawie Tyśmienicy zaczynała się już w $1446 \mathrm{r}$.

${ }^{68}$ AGZ, T. 14, nr 2104, 3803.

${ }^{69}$ Tamże, T. 12, nr 1823, 1846, 1847, 1943, 1972, 2042, 2200, 2244, 2278; T. 14, nr 1835, LXXXVIII.

70 Tamże, T. 12, nr 2153, 2288.

${ }^{71}$ Tamże, nr 2437, 2608, CXXV. O wcześniejszym zarządzaniu dobrami — Z. GóRCZAK: Rozwój majątków..., s. 268.

${ }_{72}$ Rewizja listów, k. 293v—294; Kartoteka osad ziemi lwowskiej... (Jaworów).

73 AGZ, T. 12, nr 2190, 2253, 2283; Z. GóRCZAK: Rozwój majątków..., s. 368.

74 AGZ, T. 12, nr 2832; T. 14, nr 3803. 
W tym miejscu warto wspomnieć o jeszcze jednej kwestii wiążącej się z kilkunastoletnim współposiadaniem przez księcia Wacława dóbr na Rusi Koronnej. Mianowicie, zapewne za jego sprawą w ziemi lwowskiej osiedlili się szlachcice z księstwa raciborskiego, bracia Mikołaj Klus z Pilchowic zwany Siestrzeńcem oraz Wierusz z Pilchowic. Ten pierwszy najpierw wszedł w posiadanie wsi Posworzany, a następnie (1460) z bratem kupił wieś Szydłów ${ }^{75}$.

Małżeństwo Wacława z Małgorzatą trwało zaledwie 11 lat. Książę zmarł 29 października 1456 roku, niewiele przekroczywszy 40. rok życia; został pochowany w klasztorze Dominikanek w Raciborzu ${ }^{76}$. Z małżeństwa pozostały trzy córki: Katarzyna, Helena i Anna, oraz syn Janusz (Jan) ${ }^{77}$.

W związku z tym, że następca tronu, Jan, był niepełnoletni, władzę w księstwie przejęła księżna Małgorzata. W tej roli — jako księżna i wdowa 26 czerwca 1457 roku zawarła ona układ z Królestwem Polskim, podpisany w Raciborzu, a mający zwalczać rozboje szerzące się na pograniczu śląsko-polskim ${ }^{78}$. Przez następne kilka lat Małgorzata uczestniczyła w zarządzaniu księstwem, najpierw czyniła to jednak samodzielnie, jak wskazuje dokument z 3 lipca 1461 roku, kiedy sprzedała kanonikowi Johanowi 10 grzywien czynszu z Raciborza na wyderkaf ${ }^{79}$. W 1464 roku na dokumentach obok księżnej występuje już jej syn Janusz, co świadczyłoby, że został dopuszczony do sprawowania władzy, ale jeszcze się nie usamodzielnił. 9 kwietnia tego roku obydwoje zawarli ugodę z Wacławem rybnickim i Janem karniowskim w sprawie wzajemnych rozliczeń dotyczących Raciborza i Pszczyny. Pośrednikiem oraz arbitrem w tym sporze był książę cieszyński Przemek i to on po rozpa-

75 Tamże, T. 19, nr 2783; Katalog dokumentów pergaminowych ze zbiorów Tomasza Niewodniczańskiego w Bittburgu. Oprac. J. Tomaszewicz, M. ZDANeK. Red. W. BukowsKi. Kraków 2004, nr 79; J. Sperka: Z dziejów migracji rycerstwa ślaskiego na ziemie Rusi Koronnej w końcu XIV $i$ w poczatkach XV wieku (wstępne rozpoznanie). W: Narodziny Rzeczypospolitej. Studia z dziejów średniowiecza i czasów wczesnonowożytnych. Red. W. Bukowski, T. JUREK. T. 1. Kraków 2012, s. 537-538.

${ }^{76}$ Ratiborer Chronik..., s. 118 (Item Anno MCCCCLVI obit dux Wenceslaus feria sexta ante Omnium sanctorum). Miejsce pochówku księcia podał tylko Jan Długosz, który jednocześnie zamieścił błędną datę śmierci — ostatni dzień października 1457 r. — Annales, lib. 12 [2003], s. 294 = Roczniki, ks. 12 [2004], s. 331 (tu natomiast błędne tłumaczenie - in monasterio sanctimonialium ordinis Predicatorum - i podane, że spoczął w klasztorze dominikanów). W związku z tym w literaturze historyczno-genealogicznej można spotkać się z rozbieżnościami na temat daty śmierci. Poprawną datę — 29 października 1456 r. — podają: F. Kopetzky: Zur Geschichte und Genealogie..., s. 88; H. Grotefend: Stammtafeln der Schlesischen Fürsten..., s. 21, 58, tab. 12; F. Chосноlatý: Genealogie opavských Přemyslovců..., s. 151. Błędną z kolei — 29 października 1457 r. — wymieniają: W. DworzaczeK: Genealogia..., tab. 11; W. Brzezıński: Koligacje małżeńskie..., s. 162; SHGPoz, Cz. 4, s. 793.

77 Annales, lib. 12 [2003], s. 294 = Roczniki, ks. 12 [2004], s. 331; H. Grotefend: Stammtafeln der Schlesischen Fürsten..., s. 21, 58, tab. 12; W. DworzaczeK: Genealogia ..., tab. 11.

${ }^{78} \mathrm{KDP}, \mathrm{T} .4$, nr 45; SRS Sommersberg, Bd. 2, s. 89.

79 A. Weltzel: Geschichte der Stadt und Herschaft Ratibor. Ratibor 1881, s. 648. 
trzeniu roszczeń Wacława i Jana wobec Małgorzaty i Janusza odrzucił je na korzyść strony raciborskiej. Uznał, że bezprawne są roszczenia Jana do domów w Raciborzu, do relikwii, w tym trzech cierni, znajdujących się w kaplicy zamkowej, które podobnie jak przechowywane w tym miejscu dokumenty miały tam pozostać. Natomiast do najbliższego dnia św. Michała (29 września) Jan i Wacław mieli wypłacić Małgorzacie oraz Januszowi zaległe 100 grzywien dotyczące rozliczeń za Pszczynę, którą kiedyś przejął ich ojciec Mikołaj, brat Wacława, po ich matce Helenie ${ }^{80}$. Małgorzata raciborska ostatni raz została odnotowana 20 października 1464 roku, kiedy razem z synem Januszem wystawiła dokument uwalniający od czynszów i robocizny znajdujący się w Raciborzu (koło klasztoru dominikanek) ogród niejakiego Eberharda ${ }^{81}$. Księżna zmarła 2 tygodnie później, 5 listopada 1464 roku. Została pochowana w Raciborzu, w tamtejszym klasztorze dominikanek, u boku swego męża w kaplicy św. Dominika; kaplicę niestety rozebrano w 1815 roku, a losy szczątków książęcych nie są znane ${ }^{82}$.

Jeszcze za życia księżnej Małgorzaty jej dwie córki, Katarzyna i Helena, podtrzymały tradycję zawierania związków małżeńskich z elitą wielkopolską. Starsza z nich, Katarzyna, urodziła się — biorąc pod uwagę, że ślub jej rodziców odbył się po 25 grudnia 1444 roku a przed 19 stycznia 1445 roku — najwcześniej w końcu 1445 roku, a zapewne trochę później, w 1446 roku $^{83}$. W połowie 1461 roku była już żoną Władysława (Włodka) z Danaborza, kasztelana nakielskiego (1453-1467), jednocześnie tamtejszego starosty (1436-1467) i starosty człuchowskiego (1455-1464). Terminus ante quem interesującego nas małżeństwa to 5 czerwca 1461 roku, kiedy przed sądem grodzkim w Gnieźnie Włodek z Danaborza wystąpił wspólnie z księżną Małgorzatą raciborską i Anną, wdową po Wincentym z Szamotuł, jako strona ugody majątkowej zawieranej z kasztelanem poznańskim Piotrem z Szamotuł i jego bratankami, Janem Starszym i Janem Młodszym Świdwami. Włodek w tym sporze mimo że nie zaznaczono tego $\mathrm{w}$ zapisce — reprezentował bez wątpienia swoją

${ }^{80}$ CDSil, T. 6, nr 268, s. 87; A. Weltzel: Geschichte der Stadt und Herschaft Ratibor..., s. 92. Odnośnie do rozliczeń dotyczących Pszczyny zob. J. Sperka: Pszczyna i ziemia pszczyńska..., s. 92-93.

81 A. Weltzel: Geschichte der Stadt und Herschaft Ratibor..., s. 649.

82 Annales, lib. 12 [2005], s. 99-100= Roczniki, ks. 12 [2006], s. 109; O. BAlzER: Genealogia Piastów..., s. 505; W. Korta: Matgorzata z Szamotut..., s. 443. Jeśli chodzi o pochówek księżnej, to w SHGPoz, Cz. 4, s. 793 podano błędną informację, że spoczęła ona w klasztorze Dominikanów (!) w Raciborzu.

${ }^{83}$ W. BrzezıŃski (Koligacje małżeńskie..., s. 186), wychodząc z założenia, że małżeństwo Wacława raciborskiego z Małgorzatą Szamotulską zawarto w 1443/1444 r., uważał, że ich córka Katarzyna osiągnęła lata sprawne (12 lat) w 1456 lub 1457 r. i wyszła za Danaborskiego w końcu lat 50. lub na początku lat 60 . Biorąc jednak pod uwagę, że do małżeństwa księcia raciborskiego z Szamotulską doszło - jak starałem się udowodnić — później, pozostałe obliczenia należy skorygować. 
żonę Katarzynę $e^{84}$. Przypuszczam, że do małżeństwa doszło niewiele wcześniej, zapewne w 1. poł. 1461 roku.

Małżonek księżnej Katarzyny wywodził się z jednej z gałęzi starego i zasłużonego rodu Pałuków, a jego bezpośredni protoplaści pisali się z Danaborza w powiecie kcyńskim (w województwie kaliskim). Ojcem Włodka był Andrzej z Danaborza, wojewoda kaliski (zm. 1436), a dziadem — Włodek z Danaborza, wojewoda inowrocławski z czasów rządów na Kujawach księcia Władysława Opolczyka. Rodzina Danaborskich była zamożna, chociaż w połowie XV wieku nie należała do ścisłej elity wielkopolskiej. W rękach Włodka było ok. 20 wsi dziedzicznych i 2 miasta oraz królewszczyzny, z których najważniejszą było odziedziczone po ojcu starostwo nakielskie, dzierżone na zasadzie zastawu królewskiego ${ }^{85}$. Włodek, zanim poślubił księżniczkę raciborską, był żonaty z Witochą, córką Wojciecha z Pakości i Krotoszyna (herbu Laska), kasztelana śremskiego. Miał z nią jedno dziecko - córkę Febronię, która wyszła (ok. 1470) za Mikołaja Działyńskiego z Woli (herbu Ogon), dostojnika z ziemi dobrzyńskiej (podkomorzego brzeskiego, później kasztelana dobrzyńskiego i ostatecznie wojewodę inowrocławskiego) ${ }^{86}$.

Katarzyna raciborska wniosła Włodkowi połowę dóbr, które przypadły jej po matce i babce, a mianowicie: połowę miasta Stobnicy z młynem Hamer oraz połowy wsi: Gąsawy, Popowo (Popówko), Piotrkowo, Sycyn, Jaryszewo, Brączewo, Podlesie i Turostowo, a także jedną czwartą wsi Bądlino ${ }^{87}$. Dobra te stały się jednak zarzewiem ciągłych konfliktów z Szamotulskimi, w które został wciągnięty też Danaborski. Wspomniana ugoda z 5 czerwca 1461 roku obrazowała te bardzo napięte stosunki rodzinne. Zgodnie z wyrokiem sądu Piotr Szamotulski miał uwolnić pojmanych ludzi Włodka, a ten wydać sól i konie zabrane ludziom Piotra. Dalej postanowiono, że Piotr nie będzie czynił przykrości stryjence Annie i będzie ją szanować, natomiast pannie Helenie

${ }^{84}$ GGn 2, k. 1ov-2; S. SzyBKowski: Związki rodzinne Danaborskich z elita urzędniczą Kujaw i ziemi dobrzyńskiej. Rocz. Hist. 2000, T. 66, s. 163; W. Brzezıński: Koligacje matżeńskie..., s. 186.

85 A. Boniecki: Herbarz polski. T. 4. Warszawa 1901, s. 72-73; A. GĄsiorowski: Urzędnicy zarządu lokalnego w późnośredniowiecznej Wielkopolsce. Poznań 1970, s. 104-105, 108-109 (w rękach jego synów w 1493 r. było 21 wsi i 2 miasta — AGAD, MK 15, k. 164), 159-160, 226; A. GĄSIOROWski: Starostowie wielkopolskich miast..., s. 52_53; UrzWp, nr 328, s. 138, 590; s. 168; S. SzyBкowski: Zwiazki rodzinne Danaborskich..., s. 157-164; J. SperkA: Otoczenie Władysława Opolczyka w latach 1370-1401. Studium o elicie władzy $w$ relacjach $z$ monarcha. Katowice 2006, s. 348-350.

86 S. SzyBKowski: Związki rodzinne Danaborskich..., s. 157-164; TENŻE: Kujawska szlachta urzędnicza w późnym średniowieczu (1370-1501). Gdańsk 2006, s. 620; TENżE: Kościeleccy ze Skępego herbu Ogon i ich protoplaści. Studium z dziejów późnośredniowiecznej rodziny możnowładczej. Gdańsk 2018, s. 415.

87 Dobra te przekazała swoim synom w 1493 r. — GPoz 10, k. 186v; SHGPoz, Cz. 3, s. 676. O połowie Turostowa posiadanej do 1488 r. i sprzedanej Janowi Ostrorogowi zob. tamże, s. 500 . 
(księżnej raciborskiej) zwróci dom w Szamotułach. Spory o dobra ziemskie, o zniszczenie domu (zapewne Anny) w Stobnicy, o dokumenty, pieniądze i klejnoty po Wincentym Szamotulskim miały zostać zawieszone; Piotr Szamotulski miał też przerwać budowę zamku w dobrach Anny ${ }^{88}$. Zawarta ugoda nie zapobiegła niestety kolejnym sporom. W 1465 roku toczył się proces księżnych Katarzyny i Heleny z Piotrem Szamotulskim o użytkowanie lasów w okolicach Stobnicy i Brączewa. 24 czerwca sąd ziemski odesłał jednak sprawę na sejm do Piotrkowa, gdzie Piotr został zobligowany do złożenia przysięgi, że wieś Brączewo powstała na obszarze dóbr oraz lasów należących do Stobnicy i od 50 lat - i dokonania działów — razem z ojcem korzystali z tych lasów; warunkiem dalszego ich użytkowania miało być wpłacenie odszkodowania Katarzynie i Helenie, właścicielkom Stobnicy i Brączewa ${ }^{89}$. W tym samym roku (1465) Katarzyna, Helena, Anna i Janusz, książęta raciborscy, mieli kolejny konflikt z Piotrem Szamotulskim - tym razem o Pamiątkowo i Radzyny ${ }^{90}$. Natomiast $\mathrm{w}$ grudniu tego roku książęca trójka rodzeństwa toczyła jeszcze spór z Janem, Dobrogostem i Mateuszem, synami Zachariasza z Kąsinowa ${ }^{91}$.

Dla Włodka z Danaborza małżeństwo z Katarzyną raciborską było niewątpliwie bardzo prestiżowe. Wiązało go bowiem nie tylko z domem książąt opawsko-raciborskich, ale także z bardzo znaczącymi na terenie Wielkopolski Nałęczami z Szamotuł (chociaż w tym przypadku obróciło się to przeciw niemu). Nie potrafię natomiast odpowiedzieć na pytanie, kto był inicjatorem tego związku: Danaborski czy Małgorzata, i przy jakiej sposobności to się stało. Jeśli jednak była to księżna, która co jakiś czas pojawiała się w Wielkopolsce w związku ze sprawami majątkowymi, to trudno zrozumieć, co ją skłoniło, aby swoją córkę wydać za osobę przecież nie aż tak majętną (można powiedzieć: za średniaka wśród możnych), nie pierwszej młodości, wdowca, a w dodatku jeszcze awanturnika, ze skłonnościami do okrucieństw. Jego „wyczyny” podczas toczącej się wojny z Krzyżakami, w której brał aktywny udział, były powszechnie znane $^{92}$. Od 1455 roku posiadał na prawach tenuty bardzo ważny strategicznie zamek w Człuchowie, gdzie utrzymywał na koszt króla załogę ${ }^{93}$. Jednak trudności z wypłatą należności powodowały, że władca zapisywał mu kolejne sumy na dobrach królewskich i szedł na dalsze ustępstwa ${ }^{94}$, natomiast Włodek

${ }^{88}$ SHGPoz, Cz. 4, s. 790-791; Z. GóRCZAK: Rozwój majątków..., s. 307, 372; GGn 2, k. $10 \mathrm{v}-2$.

${ }^{89}$ SHGPoz, Cz. 1, s. 103; Cz. 3, s. 499; Cz. 4, s. 791; ZPoz 18, k. 89v-90v.

90 ZPoz 18, k. 102-102v; SHGPoz, Cz. 4, s. 32 (tu jednak Annę raciborską błędnie utożsamiono z Anną, wdową po Wincentym Szamotulskim; zob. dalej na ten temat).

${ }^{91}$ ZPoz 18, k. 109v.

${ }^{92}$ M. BiskuP: Trzynastoletnia wojna z Zakonem Krzyżackim 1454-1466. Warszawa 1967, s. 171.

93 Tamże, s. 412, 458, 521.

${ }^{94}$ W 1458 r. (6 maja) król zapisał Włodkowi na utrzymanie zamku 1000 florenów na mieście Budzyniu i wsi Podstolice w powiecie kcyńskim. Z kolei w następnym roku (29 stycznia 
zaczął dopuszczać się grabieży, aby należne pieniądze zdobyćc ${ }^{95}$. O pierwszych takich ekscesach słyszymy jeszcze w 1458 roku, a nasilenie działań wobec dóbr arcybiskupich i szlacheckich nastąpiło od wiosny 1460 roku. Jednak 19 lipca tego roku w Poznaniu król zawarł porozumienie z Włodkiem, uwalniając go od winy i przyrzekając spłaty poszkodowanym. Zapewnił mu także spłatę 12000 florenów, które zapisał na starostwie człuchowskim, dalsze 7000 miał spłacić do połowy następnego roku, a odtąd aż do końca wojny miał mu wypłacać $3000^{96}$. Latem 1461 roku oddał mu jeszcze - zgodnie z wcześniejszą umową — zdobyty Frydląd, który niestety już kilka miesięcy później został utracony ${ }^{97}$. Włodek uczestniczył w wojnie trzynastoletniej, odnosząc niekwestionowane sukcesy (np. 17 września 1462 roku pokonał oddziały krzyżackie pod Świeciem), ale też prowadząc działania, które nosiły znamiona awanturniczych, prowadzonych we własnym interesie i stojących w sprzeczności z polityką królewską. Już w 1462 roku oskarżano go, że zachęcił najemników z Chojnic do najazdu w czerwcu tego roku na Pałuki ${ }^{98}$. W tym czasie Włodek zaczął przejawiać niczym nieusprawiedliwione okrucieństwo, jak w przypadku załogi Człuchowa w 1463 roku. Wtedy to bowiem burgrabia zamku Jurga z Rzucewa przeszedł na stronę wrogów i zamierzał wydać im zamek. Został jednak uwięziony przez swoich kompanów, którzy podporządkowali się królowi, a ten dał im gwarancje bezpieczeństwa. Nie uszanował jednak tego Włodek, który dwunastu z nich uwięził, a następnie zabił w okrutny sposób, wbijając ich na pale lub wyrzucając katapultą z zamku ${ }^{99}$. Kolejny raz anarchistyczne skłonności Włodka dały o sobie znać w sierpniu 1465 roku, kiedy przeciągnął na swoją stronę 500 nieopłaconych zaciężnych i wystąpił przeciw władcy. W końcu września, po wcześniejszej groźbie ze strony króla i rady oblężenia Nakła i Danaborza, udało się jednak doprowadzić do ugody, zapobiegając wojnie domowej. W Inowrocławiu Wło-

1459 r.) monarcha obiecał, że będzie przekazywał mu na utrzymanie zamku 2500 florenów, a Włodek będzie mógł korzystać z dochodów starostwa człuchowskiego, natomiast w razie odzyskania Chojnic, Frydlądu (dziś: Debrzno) i Hamersteinu (dziś: Czarne) odda mu je w zarząd - CE, T. 1, nr 163, 170; M. BISKUP: Trzynastoletnia wojna ..., s. 521, 540.

${ }_{95}$ CE, T. 1, nr 163; M. BISKUP: Trzynastoletnia wojna..., s. 521.

${ }^{96}$ CE, T. 1, nr 177-179; W. Мiкrot: Włodko z Danaborza, kasztelan nakielski i jego stosunki z Kazimierzem Jagiellończykiem. W: Album uczacej się młodzieży polskiej Józefowi Ignacemu Kraszewskiemu z powodu jubileuszu jego pięćdziesięcioletniej działalności literackiej. Lwów 1879, s. 210—238; M. BIsKuP: Trzynastoletnia wojna..., s. 571—572.

${ }_{97}$ Annales, lib. 12 [2003], s. 362 = Roczniki, ks. 12 [2004], s. 407; M. BiskuP: Trzynastoletnia wojna..., s. 592, 615.

98 Annales, lib. 12 [2005], s. 34, 44-45= Roczniki, ks. 12 [2006], s. 37, 50.

99 Annales, lib. 12 [2005], s. 58-59, 184-185 = Roczniki, ks. 12 [2006], s. 64-65, 193-194. J. Długosz podaje także, że kiedy latem 1466 r. miasta Frydląd i Hamerstein poddały się królowi Kazimierzowi Jagiellończykowi, mówiono, że wcześniej odstąpiły od niego z powodu surowości i okrucieństwa kasztelana nakielskiego Władysława - Annales, lib. 12 [2005], s. 145 = Roczniki, ks. 12 [2006], s. 154. 
dek ponownie ukorzył się przed monarchą, a ten darował jemu i jego ludziom występki oraz przywrócił ich do łask ${ }^{100}$.

Nie przywróciło to jednak wzajemnego zaufania. Włodek z Danaborza nadal miał pretensje do króla, że ten nie uregulował swoich zobowiązań wobec niego, co spowodowało, że ponownie sam postanowił odebrać należności. Jak podał Długosz, kasztelan nakielski najpierw usiłował zdobyć zamek w Człuchowie, a po niepowodzeniu zaczął pobierać daninę w bydle z okręgu człuchowskiego, a ze starostwa nakielskiego daninę pieniężną. Takie postępowanie doprowadziło do tego, że w maju 1467 roku na sejmie w Piotrkowie nakazano mu, aby wyznaczył poręczycieli, którzy zagwarantują, że nie będzie wszczynał buntu i wojny domowej w Królestwie. Włodek jednak odmówił złożenia poręki, co skutkowało tym, że 13 maja został schwytany i przekazany staroście generalnemu Wielkopolski Piotrowi z Szamotuł. Następnie doprowadzono go do Kalisza i tam został z jego rozkazu ścięty. Długosz podał, że egzekucję wykonano następnego dnia, czyli 14 maja. Historycy podważyli jednak tę datę, ponieważ jeszcze 21 maja Włodek żył. Wtedy bowiem — jak świadczy wpis do ksiąg konsystorza gnieźnieńskiego — chcąc zadośćuczynić mansjonarzom gnieźnieńskim, którym wcześniej wyrządził wiele szkód w ich dobrach, zapisał im 20 grzywien na wsi Czesławice (koło Wągrowca) ${ }^{101}$. W tej sytuacji należy przyjąć, że wyrok wykonano 21 maja lub wkrótce po tej dacie. Długosz, komentując te wydarzenia, dodał, że egzekucja Włodka wywołała powszechną aprobatę, gdyż stracono buntownika i okrutnika zarazem, grabieżcę dóbr arcybiskupstwa gnieźnieńskiego, a nawet oskarżanego o bicie fałszywej monety. Kronikarz wspomniał na koniec, że Włodkowi nie pomogło ani to, że wywodził się z wysoko postawionego rodu, ani znakomite małżeństwo z córką księcia raciborskiego Wacława ${ }^{102}$.

Włodek z Danaborza osierocił dwóch nieletnich synów o imieniu Jan, odróżnianych w źródłach przydomkami Starszy i Młodszy ${ }^{103}$. W wyborze tego imienia można doszukać się wpływów płynących z dynastii Przemyślidów raciborskich, gdzie było ono bardzo popularne. Wyrok śmierci wykonany na Włodku pociągnął za sobą utratę przez rodzinę dóbr królewskich, przede wszystkim bogatego starostwa nakielskiego, które Kazimierz Jagiellończyk w 1467 roku powierzył Maciejowi ze Słupów, a potem oddał Janowi z Górki,

100 Annales, lib. 12 [2005], s. 111-112 = Roczniki, ks. 12 [2006], s. 122-123; CE, T. 1, nr 200; W. Мiкrot: Włodko z Danaborza..., s. 234-235; M. Biskup: Trzynastoletnia wojna..., s. 680 .

101 J. Nowacki: Analecta gnieźnieńskie IV. (Przed straceniem Włodka z Danaborza kasztelana i starosty nakielskiego). Rocz. Hist. 1935, T. 11, s. 67-68; A. GĄsıorowski: Wielkopolska w ostatnich księgach Roczników Jana Dlugosza. Do Rozbioru krytycznego Annalium z lat 1385-1480. St. Źr. 1970, T. 15, s. 183.

102 Annales, lib. 12 [2005], s. 184-185 = Roczniki, ks. 12 [2006], s. 193-194.

103 A. Boniecki: Herbarz polski..., s. 72-73; S. SzyBкowski: Zwiazki rodzinne Danaborskich..., s. 163. 
podkomorzemu poznańskiemu; ten trzymał je w latach 1468 - 1477 ${ }^{104}$. Familia straciła też mniejsze dobra królewskie - Podstolice, Przebienice i Bydzyń które monarcha zezwolił wykupić Mikołajowi Działyńskiemu, zięciowi zmarłego, z rąk synów Włodka, Jana Starszego i Jana Młodszego (za zgodą ich tutora Łukasza Górki, wojewody poznańskiego), w 1470 roku (14 grudnia) jako zabezpieczenie posagu Febronii, siostry przyrodniej braci, a żony Działyńskiego ${ }^{105}$.

Ostatni akt tej tragicznej sprawy rozegrał się na sejmie w Piotrkowie, który rozpoczął się 9 października 1468 roku. Wdowa po Włodku, księżna Katarzyna, wsparta przez krewnych męża, wniosła wówczas skargę przeciw Piotrowi z Szamotuł, oskarżając go, że skazał Włodka na śmierć z powodu niechęci do niego, a także bez wiedzy króla. Szamotulski przezornie opuścił zjazd, aby nie można było podjąć jakichś decyzji wobec nieobecnego. Długosz twierdził, że choć członkowie rady potępiali wyrok śmierci wykonany na Włodku, to w przypadku większości z nich zachodziły rozbieżności między tym, co mówili, a tym, co myśleli; dodatkowo, nie padły żadne propozycje rozwiązania problemu ${ }^{106}$. Czy rzeczywiście zarzut samowolnego działania Piotra z Szamotuł był zasadny? Wpis komemoracyjny (niestety uszkodzony) z księgi grodzkiej kaliskiej podaje, że Włodek znalazł się w Kaliszu z rozkazu króla („ex mandato [domini] Kasimiri regis Polonie”); oczywiście można brać pod uwagę i taką ewentualność, że zapiska nie jest obiektywna ${ }^{107}$. Jeśli natomiast chodzi o zarzut niechęci osobistej Szamotulskiego do Danaborskiego, to biorąc pod uwagę wspomniane wcześniej konflikty między nimi, ciągnące się od 1461 roku, może mieć on jakieś uzasadnienie, chociaż dowieść tego nie sposób. Faktem jest natomiast, że niedługo po sejmie piotrkowskim synowie rozpoczęli długotrwałe procesy i zabiegi o odzyskanie królewszczyzn, które monarcha zajął po aresztowaniu, a następnie ścięciu ich ojca. Po 10 latach, w 1477 roku, udało się braciom odzyskać starostwo nakielskie, które przez następne lata wspólnie dzierżyli. O powrocie do łask królewskich bez wątpienia świadczyło zaś objęcie przez Jana Starszego urzędu kasztelana rogozieńskiego w $1485 \mathrm{roku}^{108}$.

Księżna raciborska Katarzyna po śmierci Włodka nie wyszła ponownie za mąż. Następne lata poświęciła na wychowanie synów i prowadzenie spraw majątkowych. W tym ostatnim miała już doświadczenie, gdyż jeszcze za ży-

104 A. GĄSIOROwSKi: Starostowie wielkopolskich miast..., s. 52-53; TENŻE: Wielkopolska w ostatnich księgach..., s. 183; UrzWp, nr 591-593, s. 168-169.

${ }^{105}$ Inventarium, s. 289. W 1485 r. wsie te Mikołaj Działyński za zgodą króla zastawił Przecławowi z Potulic za 1600 florenów — tamże, s. 302.

106 Annales, lib. 12 [2005], s. 224-225 = Roczniki, ks. 12 [2006], s. 235.

107 A. Gąsıorowski: Wielkopolska w ostatnich księgach..., s. 183; AP Poznań, Księga grodzka kaliska 24, k. 354v.

108 A. GĄsıorowski: Starostowie wielkopolskich miast..., s. 52-53; UrzWp, nr 593, s. 169, nr 526, s. 160 . 
cia małżonka przeprowadzała samodzielnie transakcje. W 1465 roku Katarzyna podjęła nieudaną próbę poszerzenia dóbr rodzinnych. Ponieważ Stanisław Ostroróg, wojewoda kaliski (teść jej siostry Heleny), był dłużny księżnej 1000 florenów, sprzedał jej za tę sumę połowę miasta Stobnicy, połowę wsi Brączewo i Podlesie oraz jedną czwartą Bądlina. Transakcja opatrzona była jednak prawem odkupu przez sprzedającego, co zostało po pewnym czasie zrealizowane $^{109}$. Z kolei w 1481 roku Katarzyna sprzedała Janowi Ostrorogowi część miasta Koźminek z pobliskimi wsiami: Złotniki, Chodybki, Słowiki i Dębsko (powiat kaliski), za 1100 florenów, natomiast w 1488 roku Stanisławowi Ostrorogowi (synowi Jana) połowę Turostowa za 600 grzywien ${ }^{110}$. Księżna wykazywała także duże zainteresowanie sprawami Kościoła, dokonując kilkakrotnie donacji (lub transakcji) na rzecz różnych jego instytucji: w 1471 roku zapisała kapitule katedralnej poznańskiej roczny czynsz 10 grzywien od sumy 100 kop groszy ze wsi Sycyn i Piotrkowo; w 1478 roku, wraz z synami, zapisała Pawłowi, penitencjarzowi w katedrze poznańskiej i prebendarzowi w kolegiacie Najświętszej Marii Panny (koło katedry poznańskiej), czynsz roczny 5 grzywien z Popówka, z zastrzeżeniem prawa wykupu za 60 grzywien; w 1482 roku sprzedała, z zastrzeżeniem prawa wykupu, mansjonarzom w Szamotułach czynsze z Popowa i Gąsawy (10 grzywien od 100 kop groszy i 2 grzywny od sumy 24 grzywien), natomiast w 1492 roku zapisała czynsz roczny 10 grzywien od sumy 100 kóp półgroszy ze wsi Popówka i z folwarku Gąsawy mansjonarzom w kościele parafialnym w Szamotułach ${ }^{111}$.

Tuż przed śmiercią, 26 maja 1493 roku przekazała wszystkie dziedziczne dobra swoim synom (połowę miasta Stobnicy z młynem Hamer oraz połowy wsi: Gąsawy, Popowo, Piotrkowo, Sycyn, Jaryszewo, Brączewo, Podlesie, i jedną czwartą wsi Bądlino) ${ }^{112}$. Było to ostatnie znane nam wystąpienie Elżbiety zmarła wkrótce po tej dacie. Dnia 12 czerwca 1493 roku w Poznaniu król Jan Olbracht, pod wadium 1000 florenów, zatwierdził już podział dóbr między jej synami, Janem Starszym i Janem Młodszym Danaborskimi ${ }^{113}$. Wszystko zatem wskazuje, że Katarzyna raciborska zmarła wkrótce po 26 maja 1493 roku.

Helena, księżna raciborska - imię otrzymała niewątpliwie po babce, Helenie Korybutównie — po raz pierwszy pojawia się w źródłach 5 czerwca 1461

109 ZPoz 18, k. 87; SHGPoz, Cz. 3, s. 498, 710. Z. GóRCZAK (Rozwój majątków..., s. 307) podaje błędnie, że wymienione wsie Stanisław Ostroróg zastawił (a nie sprzedał) Włodkowi z Danaborza.

${ }^{110}$ GPoz 9, k. 137v; 10, k. 99; Z. GórczaK: Rozwój majątków..., s. 316; SHGPoz, Cz. 3 , s. 500-501 (tu podano, że sprzedała dobra koźmińskie Janowi i Stanisławowi; w rzeczywistości Katarzyna przeprowadziła transakcję ze Stanisławem, synem Jana Ostroroga; omyłkowo wymieniono też kwotę 1000 florenów).

${ }_{111}$ SHGPoz, Cz. 3, s. 676 (Piotrkowo), 784 (Popówko); Cz. 4, s. 768 (Szamotuły).

112 GPoz 10, k. 186v; SHGPoz, Cz. 3, s. 676, 710; W. BRZEZIŃSKI (Koligacje matżeńskie..., s. 186) podaje błędnie, że Katarzyna sprzedała (a nie dała) synom wymienione wsie.

113 AGAD, MK 15, k. 164. 
roku, kiedy wspomniano ją w ugodzie zawartej między Piotrem z Szamotuł, Janem Młodszym i Janem Starszym Świdwami a księżną Małgorzatą raciborską i Anną, wdową po Wincentym z Szamotuł. Jak wynika z treści zapiski, wcześniej została bezprawnie usunięta $\mathrm{z}$ domu w Szamotułach; była w tym czasie już pełnoletnia, ale jeszcze niezamężna (określona jako „virgo") ${ }^{114}$. Kolejny raz księżna pojawia się w źródłach 29 listopada 1463 roku, kiedy w zapisce w księdze ziemskiej poznańskiej odnotowano, że Helena, niegdyś z Popowa (,olim de Popowo”), ofiarowała wieś Radzyny Janowi z Ostroroga, synowi Stanisława Ostroroga ${ }^{115}$. Nie jest tam jednak nazwana żoną Jana ani on jej mę$\dot{z ̇ e m}^{116}$. Jako żona Jana Ostroroga występuje dopiero 11 maja 1464 roku w aktach konsystorza gnieźnieńskiego, przed którym prokurator Stanisław Ostroróg, wojewoda kaliski, występował w imieniu Heleny i syna Jana w sprawie o Baworowo z Janem Gyeczm, altarystą w kościele Marii Magdaleny w Poznaniu $^{117}$. Należy więc przypuszczać, że małżeństwo zawarto w Boże Narodzenie 1463 roku albo zaraz na początku 1464 roku, natomiast wcześniejsza darowizna dokonana przez Helenę (jeszcze w okresie adwentu) była gestem dobrej woli na poczet posagu wobec przyszłego męża. Dobra wniesione przez księżną obejmowały: pół miasta Stobnicy, dwie całe wsie: Baworowo i Radzyny, cztery wsie w połowie: Brączewo, Pamiątkowo, Podlesie i Turostów, oraz 1/4 Bądlina ${ }^{118}$. Jako dziedziczka tych wsi odnotowana została 7 marca 1469 roku, kiedy procesowała się z mieszczanami z Szamotuł ${ }^{119}$.

Mąż Heleny, Jan Ostroróg (zm. 1501), był jedynym synem Stanisława Ostroroga (zm. 1476/1477) i Beaty z Bystrzycy, a wnukiem Sędziwoja z Ostroroga herbu Nałęcz, należącego do ścisłego grona doradców Władysława Jagiełły. Stanisław, ojciec Jana, związany był z dworem królewskim od początku lat 30. $\mathrm{XV}$ wieku, ale najwyższą pozycję osiągnął za panowania króla Kazimierza Jagiellończyka, którego był bliskim współpracownikiem. Uczestniczył wtedy w najważniejszych wydarzeniach politycznych w kraju, licznych misjach dyplomatycznych i konfliktach zbrojnych, w tym zwłaszcza aktywnie zaangażował się w wojnę trzynastoletnią z Krzyżakami. Jednocześnie piął się po szczeblach kariery urzędniczej, obejmując kolejno: podkomorstwo poznańskie

114 GGn 2, k. 1ov-2.

115 ZPoz 18, k. 6; Z. GórcZAK: Rozwój majątków..., s. 307.

116 ZPoz 18, k. 6.

117 ACI, T. 2, nr 596 (wtedy Stanisław Ostroróg, wojewoda kaliski, przez swego zastępcę Simona występował w imieniu Jana Ostroroga, doktora obojga praw, i jego żony Heleny (Helene consortis sue) w sprawie o Baworowo z Janem Gyeczem, altarystą w kościele pw. św. Marii Magdaleny w Poznaniu).

${ }_{118}$ ZPoz 18, k. 89v, 102v; SHGPoz, Cz. 3, s. 499-500; Cz. 4, s. 32; Z. GórCZAK: Rozwój majątków..., s. 307.

119 ZPoz 19, k. 8v; SHGPoz, Cz. 3, s. 709 (Podlesie). Wcześniejsza - z 7 lutego 1469 r. - ta sama sprawa oraz Jana, sołtysa ze Szczepankowa, który pozwał Helenę, dziedziczkę w Stobnicy - ZPoz 19, k. 231; SHGPoz, Cz. 4, s. 815. 
(1438), podstolstwo kaliskie (1432 - 1445), starostwo generalne Wielkopolski (1439 - 1440, 1448 — 1451), kasztelanię międzyrzecką (1445 - 1449), kasztelanię gnieźnieńską (1450 - 1453), województwo kaliskie (1453-1475) i wreszcie województwo poznańskie (1475-1476). Mimo że rodzina panów z Ostroroga zaliczała się do ścisłej elity wielkopolskiej, jej majątek nie był imponujący. Szacuje się, że pod koniec życia Stanisława jego dobra stanowiły 4 miasteczka (lub ich części) i ponad 20 wsi $^{120}$. Jego syn Jan otrzymał staranne wykształcenie: w 1450 roku studiował w Wiedniu, w latach 1453-1455 w Erfurcie, a w latach 1458 - $1460 \mathrm{w}$ Bolonii, gdzie uzyskał doktorat obojga praw. Po powrocie do kraju, dzięki poparciu ojca, wtedy wojewody kaliskiego, zaczął brać czynny udział w życiu politycznym. W 1462 roku wraz z doktorem Jakubem z Szadka był członkiem komisji, która opiniowała włączenie części Mazowsza do Królestwa Polskiego, w 1464 roku posłował do Rzymu z upoważnienia króla Kazimierza Jagiellończyka, a w 1465 roku otrzymał nominację na swój pierwszy urząd: kasztelana międzyrzeckiego ${ }^{121}$. W latach następnych sprawował urząd kasztelana poznańskiego (1474-1500), był krótko starostą generalnym Wielkopolski (1493-1498), by karierę zakończyć jako wojewoda poznański $(1500-1501)^{122}$. Janowi Ostrorogowi przypisuje się zazwyczaj autorstwo słynnego memoriału o naprawie Rzeczypospolitej pt. Monumentum... po Reipublicae ordinatione, chociaż niektórzy $\mathrm{z}$ historyków wnoszą w tym względzie wiele zastrzeżeńn ${ }^{123}$.

Można przypuszczać, że małżeństwo Jana Ostroroga z Heleną raciborską było wspólną inicjatywą ich rodziców: Stanisława Ostroroga, wojewody kaliskiego, i Małgorzaty raciborskiej. Obydwoje mieli wielokrotnie okazję, aby spotkać się przy okazji spraw sądowych, które sprowadzały księżną do Wielkopolski, a w których Stanisław występował jako asesor sądowy (np. 5 czerwca 1461 roku) ${ }^{124}$. Niewykluczone także, że kiedy Stanisław Ostroróg był jednym z uczestników negocjacji polsko-czeskich w Bytomiu (1460) czy podróżował z poselstwem królewskim z Krakowa do Pragi (1462), miał okazję odwiedzić księżną w Raciborzu i sprawę ożenku syna omówić125. Prestiż dla Ostrorogów był niewątpliwy, godne i dostatnie życie dla księżniczki były oczywistością. Trzeba jednak stwierdzić, że wniesiony przez Helenę posag w postaci połowy klucza stobnickiego podobnie jak w przypadku jej

${ }^{120}$ UrzWp, nr 47, s. 104 , nr 180, s. 121 , nr 232, s. 126 , nr 491, s. 157 , nr 626, s. 173 , nr 630 , s. 174; Wielkopolscy Ostrorogowie. Red. A. GĄsIOROwSKI. Ostroróg 1998, s. 64-69, 71.

${ }^{121}$ Ostroróg Jan h. Natęcz (zm. 1501). W: PSB, T. 24, s. 502-505; J. WieSIOŁOWSKi: Ostroróg Jan. W: Wielkopolscy Ostrorogowie..., s. 77.

${ }^{122}$ UrzWp, nr 314, s. 137, nr 364, s. 142, nr 495, s. 157, nr 638, s. 175.

123 J. Wiesiolowski: Ostroróg Jan..., s. 77-78.

${ }^{124}$ GGn 2, k. lov.

125 Annales, lib. 12 [2003], s. 337, 346; lib. 12 [2005], s. 26 = Roczniki, ks. 12 [2004], s. $379-380,390 ;$ ks. 12 [2006], s. 26. 
siostry Katarzyny nie był mały, ale innym posagom książęcym tego okresu raczej nie dorównywał.

Helena jako żyjąca ostatni raz została odnotowana w źródłach 13 stycznia 1478 roku, kiedy jej brat Janusz raciborski wymienił ją wśród sióstr, które musiały udzielić mu zgody na zapis wiana dla jego żony Magdaleny opolskiej ${ }^{126}$. Księżna zmarła przed 25 lipca 1494 roku, wtedy bowiem Jan Ostroróg, kasztelan poznański, jej były mąż, wniósł do księgi grodzkiej poznańskiej zapis wiana dla swojej drugiej żony, Doroty z Wrześni ${ }^{127}$.

Z małżeństwa Heleny i Jana Ostroroga pozostało dwóch synów: Wacław (zwany też niekiedy Władysławem) i Stanisław ${ }^{128}$. Pierwszy z braci imię z pewnością otrzymał po dziadku - księciu Wacławie raciborskim.

Rozważając problem potomstwa księcia Wacława i Małgorzaty Szamotulskiej, odniosę się jeszcze do ich córki Anny występującej kilkakrotnie w źródłach, w przekazie Jana Długosza, w źródłach dyplomatycznych ${ }^{129}$, ale także w materiale sądowym. Ten ostatni przysporzył jednak sporo problemów historykom. W opracowaniach wykorzystujących te same źródła sądowe Anna raciborska mylona jest niestety z Anną, wdową po Wincentym Szamotulskim. Zbyszko Górczak — powołując się na te same źródła ${ }^{130}$ — w jednym miejscu swej pracy napisał, że w 1465 roku (w zapiskach z 3 grudnia w sprawie dotyczącej sporu z Piotrem Szamotulskim o Radzyny i Pamiątkowo) wspomniano tam pannę Annę, siostrę Katarzyny i Heleny ${ }^{131}$. Jednak w innym miejscu rozprawy uznał, że pisarz sądowy popełnił pomyłkę i zamiast Anny, wdowy po Szamotulskim, wpisał Annę raciborską ${ }^{132}$. Z kolei Paweł Dembiński identyfikował Annę z wymienionej zapiski z Anną, wdową po Wincentym z Szamotuł ${ }^{133}$.

${ }^{126}$ CDSil, T. 6, nr 306, s. 101-102.

127 GPoz 7, k. 36. Król potwierdził zapis dożywocia dokonany przez Jana Ostroroga, wystawiając dokument na sejmie radomskim 15 września 1494 r. - MRPS, T. 2, nr 429. Po śmierci Jana Ostroroga, w latach 1501-1506 toczyły się procesy między Wacławem i Stanisławem Ostrorogami a Dorotą z Wrześni. Macocha oskarżała ich, że więzili ją po śmierci męża najpierw przez 3 tygodnie w Grodzisku, a potem w Ostrorogu. Z kolei młodzi Ostrorogowie obwinili ją o to, że w 1500 r., jeszcze za życia ich ojca, potajemnie przeniosła rzeczy ze skarbca w Grodzisku do swego domu i zamku w Ostrorogu, a w skarbcu była przechowywana wyprawa ich matki Heleny - SHGPoz, Cz. 1, s. 690; Cz. 3, s. 50; A. PAwiński: Jana Ostroroga żywot i pismo o naprawie Rzeczypospolitej. Warszawa 1884, s. 205; Ostroróg Jan..., s. 505; A. Gąsionowski: Koligacje panów z Ostroroga wXV wieku. „Studia i Materiały do Dziejów Wielkopolski i Pomorza" 1980, T. 13, z. 2, s. 80-91.

${ }^{128}$ SHGPoz, Cz. 1, s. 690; Cz. 3, s. 709-710; Cz. 4, s. 33; Ostroróg Jan..., s. 505; A. GĄSIOROWSKI: Koligacje..., s. $80-91$.

129 Annales, lib. 12 [2003], s. 294 = Roczniki, ks. 12 [2004], s. 331; CDS, T. 6, s. 101-102, nr 306.

${ }^{130}$ ZPoz 18, k. 102-102v, 152-153.

131 Z. GórCZAK: Rozwój majątków..., s. 307, przyp. 229.

132 Tamże, s. 372, przyp. 135.

133 SHGPoz, Cz. 4, s. 32 (Radzyny). 
Trzeba jednak stanowczo stwierdzić, że Anna Szamotulska w zapiskach sądowych z lat 1445-1461 zawsze występuje jako Anna, wdowa po Wincentym z Szamotuł („Anna relicta olim magnifici domini Vincenti de Schamotuly”) ${ }^{134}$. Natomiast księżna Anna w zapiskach z 3 grudnia 1465 roku odnotowana jest z określeniem, że jest córką Wacława, księcia raciborskiego („Anna principissa filia principis Venceslai duce Ratiborz"), lub siostrą księcia Janusza raciborskiego (,Janussius dux in Ratiborz et Anna sorore”) ${ }^{135}$. Wniosek z tych faktów jest jednoznaczny: w zapiskach sądowych obydwie Anny są wyraźnie rozróżniane, z tym że Anna Szamotulska ostatni raz odnotowana została 5 czerwca 1461 roku, natomiast w 1465 roku występuje już księżna Anna raciborska. Ta z kolei ostatni raz jako żyjąca wspomniana jest w dokumencie swego brata Janusza raciborskiego z 13 stycznia 1478 roku, którym książę wyznaczał swojej żonie Magdalenie, księżnej opolskiej, wiano (oprawę wdowią). Zapis był jednak warunkowany zwyczajową zgodą jego sióstr: Katarzyny, Heleny i Anny, na co - jak zaznaczono - bardzo liczył. Anna zmarła po tej ostatniej dacie; nic nie wiadomo, aby wyszła za mąż lub wstąpiła do klasztoru ${ }^{136}$.

Chciałbym odnieść się do jeszcze jednej sprawy dotyczącej córek Wacława raciborskiego i Małgorzaty Szamotulskiej. Mianowicie, Zbyszko Górczak wymienił dodatkowo Barbarę, wzmiankowaną rzekomo w 1450 roku, która miała umrzeć $\mathrm{w}$ młodym wieku ${ }^{137}$. Jest to niestety ewidentna pomyłka, która wynika ze złej interpretacji zapiski sądowej. W niej bowiem — z 1451 roku (!), jak poprawnie podaje P. Dembiński - Anna, wdowa po Wincentym, zapisała w dożywocie szlachetnej Helenie w zamian za służby 5 grzywien półgroszy czynszu ze swojej wsi Radzyny. Po śmierci Heleny czynsz miało przejąć w dożywocie jej rodzeństwo: Barbara, Jan i Katarzyna, a po ich śmierci suma wró-

\footnotetext{
134 GPoz 2, k. 89, 104v (1445 r.); 4, k. 37 (1451 r.); GGn 2, k. 1ov-2 (1461 r.).

135 ZPoz 18, k. 102, 109v.
}

136 CMV, k. 13, nr 23; CDSil, T. 6, nr 306, s. 101-102. Taką datę podaje też H. GroTEFEND: Stammtafeln der Schlesischen Fürsten..., s. 21, 59, tab. 12, a za nim W. DWORZACZEK: Genealogia..., tab. 11. Natomiast F. Kopetzкy (Zur Geschichte und Genealogie..., s. 88), akceptując datę śmierci Anny, dodał jeszcze, że była opatką w klasztorze Cysterek w Trzebnicy. Powołał się przy tym na F. Sommersberga (SRS Sommersberg, Bd. 1, s. 763), który rzeczywiście podał, że Anna (w domyśle księżniczka raciborska, ponieważ wymieniona we fragmencie dotyczącym tych książąt) była w 1469 r. opatką trzebnicką, piętnastą z kolei, zmarłą w dzień Ambrosii (4 kwietnia). Jednak F. Sommersberg, zamieszczając tę informację, podparł się dziełem J. SinAPIUSA: Olsnographia oder Eigentliche Beschreibung des Oelßnischen Fürstenthums in Nieder-Schlesien. T. 2. Leipzig 1706, s. 631. Tam jednak informacja (w spisie opatek trzebnickich) ma inne brzmienie, a mianowicie, że opatka Anna, księżna opawska, zmarła 4 kwietnia 1469 r. („Anna herzogin von Troppau starb am Tage Ambrosii 1469”). To z kolei zmienia postać rzeczy i jednocześnie wyklucza możliwość — pomijając już tytulaturę, gdzie powinna występować jako herzogin von Ratibor, oraz fakt, że w zachowanych współczesnych źródłach nigdzie nie występuje jako zakonnica, a tym bardziej jako opatka — utożsamiania Anny opawskiej wymienionej przez J. Sinapiusa z Anną raciborską, która żyła jeszcze w 1478 r.

137 Z. GórczAK: Rozwój majątków..., s. 372, powołując się na GPoz 4, s. 75. 
cić miała do tejże Anny i jej spadkobierców ${ }^{138}$. Jak widać, zapiska dotyczy nie wnuków Anny, wdowy po Wincentym z Szamotuł, tylko osób mających takie same imiona, z których niejaka Helena służyła Szamotulskiej. Nie było zatem Barbary, córki Wacława raciborskiego i Anny Szamotulskiej.

Jedyny syn Małgorzaty i Wacława raciborskiego, Jan, zwany też Januszem $^{139}$, urodził się najpewniej po 1449 roku $^{140}$. Przesłanką do takiego wnioskowania jest fakt, że jeszcze jesienią 1464 roku nie wystawiał samodzielnie dokumentów, a występował u boki matki, co wskazywałoby, że nie był jeszcze pełnoletni. W źródłach dodawano mu przydomek Młodszy, dla odróżnienia od Jana (Janusza) Starszego karniowskiego ${ }^{141}$. Na początku stycznia 1478 roku był już mężem Magdaleny, córki Mikołaja I opolskiego. Bracia Magdaleny, Mikołaj II i Jan II, zapisali jej posag w wysokości 5000 florenów, a następnie z powodu wyjątkowej przyjaźni - dodali jeszcze 2000 florenów. Książę ze swej strony 13 stycznia tego roku w Opolu wyznaczył hojne wiano, zapisując też 5000 florenów i zobowiązując się dodać jeszcze 2000 florenów, jeśli tylko brat Magdaleny, Jan, wypłaci tę kwotę siostrze; wiano zabezpieczył na swoim księstwie. W przypadku braku spadkobierców jej dożywocie obejmowało całe księstwo raciborskie, natomiast gdyby miał sukcesorów, oprawa wdowia miała stanowić połowę księstwa ${ }^{142}$. Kilka dni później, 2 lutego, zobowiązał się też do uzyskania od króla Macieja Korwina zatwierdzenia tegoż układu, co także udało mu się zrealizowaćc ${ }^{143}$.

Jan Młodszy raciborski zmarł 14 kwietnia 1493 roku $^{144}$. Pozostawił z małżeństwa z Magdaleną trzech nieletnich synów: Mikołaja, Jana i Walentyna. W tej sytuacji władzę w księstwie przejęła księżna-wdowa, która z czasem dopuściła do rządów najstarszego z nich - Mikołaja. Po jej śmierci w maju 1501 roku władzę sprawowali wspólnie Mikołaj i Jan ${ }^{145}$.

${ }^{138}$ SHGPoz, Cz. 4, s. 32 (Radzyny).

139 Istotę rzeczy oddaje chyba najlepiej zapiska sądowa poznańska z 1465 r., gdzie księcia raciborskiego określono jako: Johannes seu Janussius — ZPoz 18, k. 102.

${ }^{140}$ Błędną datę urodzin księcia Jana: ok. 1440 r., a także jego ożenku z Magdaleną opolską: ok. 1470 r., podaje F. Chосноlatý: Genealogie opavských Přemyslovců..., s. 151-152.

${ }_{141}$ CDSil, T. 2, nr 88, 91-93; T. 6, nr 292, 298, 306-309, 311-312, 316-317, 342; Ratiborer Chronik..., s. 122-123.

${ }^{142}$ CDSil, T. 6, s. 101-103, nr 306, 307, 309 = LBS, T. 2, s. 397, nr 19, 20; K. JASIŃSKI: Rodowód Piastów śląskich..., s. 588; J. RaJman: Pogranicze ślasko-matopolskie w średniowieczu. Kraków 1998, s. 216.

${ }^{143}$ CDSil, T. 6, s. 102-103, nr 308, 311= LBS, T. 2, s. 398, nr 22, 25.

144 Necrolog des Kloster Czarnowanz. Hrsg. W. WATtenBaCh. ZVGAS 1856, Bd. 1, s. 227 (tu data dzienna śmierci); F. Kopetzky: Zur Geschichte und Genealogie..., s. 90; H. GroTEFEND: Stammtafeln der Schlesischen Fürsten..., s. 21, tab. 12; F. СносноLAтÝ: Genealogie opavských Přemyslovců..., s. 152.

${ }^{145}$ H. Grotefend: Stammtafeln der Schlesischen Fürsten..., tab. 12; A. Weltzel: Historia miasta Żory..., s. 56; K. JASIŃski: Rodowód Piastów śląskich..., s. 588; T. KREJČíK: Jan. V: Biografický slovnik Slezska a severni Moravy. S. 4. Opava-Ostrava 1995, s. 106 (tu błędne 
Najstarszy z braci, Mikołaj, szukając małżonki ${ }^{146}$, poszedł w ślady swoich przodków i znalazł ją w Królestwie Polskim, żeniąc się z Anną (ur. ok. 1488), córką Zbigniewa z Tęczyna herbu Topór, podkomorzego krakowskiego (zm. 1498). Dnia 31 października 1504 roku w Krakowie Aleksander, król Polski, potwierdził, że Jan i Andrzej z Tęczyna zobowiązali się wobec Mikołaja raciborskiego, że zapiszą swojej siostrze Annie w posagu miasto Pleszew z przynależnościami w powiecie kaliskim. W dokumencie Anna nie jest jeszcze nazywana żoną Mikołaja, mowa jest o tym, że do dopełnienia małżeństwa dopiero dojdzie (,,post consummatum matrimonium”), zapewne więc sfinalizowano je jakiś czas później ${ }^{147}$. Może stało się to wkrótce po 6 października 1505 roku, kiedy to Anna — określana tylko jako córka zmarłego Zbigniewa z Tęczyna, podkomorzego krakowskiego — samodzielnie występowała przed sądem ziemskim kaliskim w sporze o granice między wsiami Gostyczyna i Osiek ${ }^{148}$.

W skład posagu wniesionego przez Annę weszły miasto Pleszew i 15 wsi, a mianowicie: Baranowo Wielkie i Małe, Piekarzew, Wola Duchowna, Zawidowice, Piwonice, Zagórzynko, Russów, Gostyczyna, Łapkowo, Radzimie, Łaszew i Pacynowice w powiecie kaliskim, Potarzyca w powiecie pyzdrskim oraz Chromiec w powiecie kościańskim ${ }^{149}$. 10 czerwca 1506 roku przed poznańskim sądem grodzkim Anna zeznała, że dobra te zapisuje mężowi z zastrzeżeniem prawa wykupu za 10000 florenów $^{150}$, a starosta generalny Wielkopolski Jan Zaremba $\mathrm{z}$ Kalinowej na tej podstawie wystawił stosowny dokument ${ }^{151}$. Nie znamy natomiast dokumentu oprawy posagu wystawionego przez księcia. Można się jedynie domyślać, że kwota 10000 florenów została ubezpieczona - podobnie jak w przypadku jego ojca i matki — na połowie (lub całości)

dane z życia księcia). Datę urodzin Anny Tęczyńskiej ustalił ostatnio dr Adam Kozak w przygotowywanych Dziejach Pleszewa w średniowieczu; w tym miejscu pragnę bardzo podziękować $\mathrm{Mu}$ za udostępnienie fragmentów tej pracy.

${ }^{146}$ L. Neustadt (Beiträge zur Genealogie schlesischer..., s. 237) podał — powołując się na dokument znajdujący się w Królewskim Archiwum w Berlinie — że w 1498 r. Mikołaj raciborski był zaręczony z Anastazją, najmłodszą córką Albrechta III Achillesa Hohenzollerna, elektora brandenburskiego (zm. 1486); informacji tej nie udało mi się potwierdzić. Badacz nie wyjaśnił jednak, dlaczego nie doszło do planowanego małżeństwa; w 1500 r. Anastazja została żoną grafa Wilhelma IV von Henneberg-Schleusingen, urodziła mu liczne potomstwo, zmarła w $1534 \mathrm{r}$.

${ }^{147}$ AGAD, MK, T. 21, k. 65-65v = MRPS, T. 3, nr 1799 (regest); CMV, k. 38-40= CDSil, T. 6, s. 153-154, nr 458 (regest). J. KURTYKa (Latyfundium Tęczyńskie. Dobra i właściciele (XIV-XVII wiek). Kraków 1999, s. 175) datował małżeństwo już na ok. 31 października $1504 \mathrm{r}$.

148 A. Kozak: Dzieje Pleszewa w średniowieczu (w przygotowaniu do druku); AP Poznań, Księga ziemska kaliska 19, k. 105v-106.

${ }_{149}$ CMV, k. 48 = CDSil, T. 6, s. 155, nr 464; GPoz 13, k. 90v.

${ }_{150}$ GPoz 13, k. 90v; SHGPoz, Cz. 1, s. 221.

151 CMV, k. 48 = CDSil, T. 6, s. 155, nr 464. 
księstwa raciborskiego. Niestety szczęście młodej pary nie trwało długo, gdyż jeszcze w tym samym roku książę zachorował. Na leczenie udał się do Krakowa, ale tam, mimo wysiłków lekarzy, zmarł w nocy (o 7 godzinie) 3 listopada 1506 roku; został pochowany w Raciborzu, najpewniej w nekropolii książąt raciborskich, w klasztorze dominikanek ${ }^{152}$. Ponieważ małżeństwo było bezdzietne, Anna opuściła Racibórz i osiadła w dobrach posagowych w Pleszewie. Przez następne lata, do ponownego wyjścia za mąż ok. 1531 roku za Jana Kościeleckiego, podkomorzego dobrzyńskiego herbu Ogon (zm. 1553), niezależna osobiście i majątkowo, często tytułowana była księżną raciborską ${ }^{153}$; zmarła przed 27 sierpnia 1552 roku $^{154}$. Natomiast w księstwie raciborskim po śmierci Mikołaja rządy chwilowo przejął kolejny z braci - Jan, ale wkrótce zmarł, jeszcze w 1506 roku. W tej sytuacji władza przypadła najmłodszemu - Walentynowi. Ten, mimo że fizycznie kaleka, garbaty, z dużym wolem, pomawiany o rozpustę, z powodzeniem rządził księstwem przez kilkanaście lat ${ }^{155}$. Jako spadkobierca Mikołaja podjął nawet próbę utrzymania dóbr pleszewskich, gdzie został odnotowany w 1507 roku. Nie był jednak w stanie spłacić Anny z 10000 florenów, co skutkowało tym, że w 1508 roku (10 października) zrzekł się na jej rzecz dóbr pleszewskich ${ }^{156}$. Walentyn był ostatnim z Przemyślidów raciborskich. Nieżonaty, bezdzietny, zmarł 13 listopada 1521 roku, pochowany został $\mathrm{w}$ raciborskim klasztorze dominikanek ${ }^{157}$.

152 Chronica Polonorum [...] Mathiae de Miechovia atrium et medicinae doctoris et canonici Cracoviensis. Cracoviae 1521, s. 379; F. Kopetzky: Zur Geschichte und Genealogie..., s. 90 .

153 Tytułowana księżną raciborską w latach 1508-1532 — MRPS, T. 4, nr 2860, 6198, 14188; KDP, T. 4, nr 138, 140; SPPP. T. 6. Wyd. M. BobrzyŃsKi. Kraków 1881, nr 328; Jana Łaskiego Liber Beneficiorum Archidiecezji Gnieźnieńskiej. T. 2. Wyd. J. Łukowski. Gniezno 1881, s. $32-33$.

154 A. Kozak: Dzieje Pleszewa w średniowieczu... (tu szczegółowo o losach Anny Tęczyńskiej rezydującej w Pleszewie); zob. też: W. Dworzaczek: Kościelecki Jan. W: PSB, T. 14, s. 405—406; J. Kurtyka: Latyfundium..., s. 175.

155 Chronica Polonorum..., s. 379; T. KREJČí́K: Valentin. V: Biografický slovník Slezska..., s. 106-107; N. Mika: Przemyślidzi opawsko-raciborscy. „Ziemia Raciborska” 2006, T. 9, s. 41-56; TenżE: Ostatni Przemyślida - książę Walentyn Garbaty. W: Czechy i Polska między Wschodem i Zachodem - średniowiecze $i$ wczesna epoka nowożytna. Red. T. CIESIELSKI, W. IwAŃczaK. Warszawa-Bellerive-sur-Allier 2016, s. 54-64; J. SperkA: Do 1532 roku..., s. $161-163$.

156 A. Kozak: Dzieje Pleszewa w średniowieczu...

157 H. Grotefend: Stammtafeln der Schlesischen Fürsten..., tab. 12, s. 152; F. СносноLATÝ: Genealogie opavských Přemyslovců..., s. 152; N. MikA: Ostatni Przemyślida..., s. 6263; K. Kozıowska: Knižecí nekropole v klášteře sv. Ducha sester Dominikánek (v současnosti muzeum) w Ratiboři. „Vlastivědné listy“ 2003, roč. 29, č. 1, s. 1-3; M. ČAPSKÝ: Zlomený meč. Valentin Hrabatý, poslední z opavských Přemyslovců. „Dejiny a současnost“ 2006, 2 (Přemyslovské dědictví), s. $34-36$. 


\section{Wnioski}

Ponowna analiza materiału źródłowego dotyczącego Przemyślidów raciborskich w kontekście ich związków rodzinnych z przedstawicielami możnowładztwa polskiego w XV-początkach XVI wieku pozwoliła na wprowadzenie znaczących korekt $\mathrm{w}$ stosunku do dotychczasowej wiedzy odnośnie do faktów genealogicznych dotyczących trzech pokoleń tej dynastii, a także losów dóbr, które stawały się posagami czy wianami małżeńskimi. Z przedstawionej analizy płyną też ogólne wnioski odnoszące się do tego typu związków. Rodzinom możnowładczym wejście w związki małżeńskie $\mathrm{z}$ familiami książęcymi niewątpliwie przynosiło wielki prestiż. Dla strony książęcej poślubienie szlachcianki z rodziny możnowładczej to przede wszystkim możliwość podreperowania sytuacji finansowej za sprawą odpowiednio dużego posagu wniesionego przez małżonkę. Niewątpliwie takie małżeństwa przynosiły także obu stronom korzyści polityczne. Książętom, którzy żenili się z wysoko postawionymi szlachciankami, ułatwiały dostęp do króla polskiego, jego otoczenia oraz innych wpływowych rodzin możnowładczych. Natomiast koronnej elicie politycznej dawały bezpośredni dostęp do osoby księcia i możliwość wpływu na jego decyzje oraz polityczne wybory. Nie można tu oczywiście całkowicie pomijać kontekstu uczuciowego, chociaż akurat w przypadku analizowanych małżeństw źródła o takich aspektach nic nie wspominają. Szlachcianki, wychodząc za książąt, stawały się pełnoprawnymi księżnymi i tak były tytułowane. Nawet kiedy jako wdowy wracały w rodzinne strony do Korony, tytuł książęcy wciąż im przysługiwał, co źródła jednoznacznie potwierdzają.

\section{Bibliografia}

\section{Źródła rękopiśmienne}

Archiwum Główne Akt Dawnych: Metryka Koronna, T. 15, 21; Metryka Litewska, Dz. IV B., sygn. 9 [Księga wpisów przywilejów na dobra w województwie ruskim przedkładanych podczas ,rewizji listów” w 1563/1564].

Archiwum Państwowe w Poznaniu: Księga grodzka gnieźnieńska 2; Księga grodzka kaliska 24; Księga grodzka poznańska 2, 4, 7, 9, 10, 13; Księga ziemska kaliska 19; Księga ziemska poznańska 15,18 . 
Centrum Informacji Naukowej i Biblioteka Akademicka w Katowicach, Copiarius monasteri ad S. Venceslaum. Diplomatarius Silesiacarum - mikrofilm, sygn. Mf. 166, 1-2 (oryginał w Bibliotece Narodowej w Pradze, sygn. 6 XVI 8).

Kartoteka osad ziemi lwowskiej w Pracowni Słownika Historyczno-Geograficznego Małopolski w Instytucie Historii PAN w Krakowie.

\section{Źródła drukowane}

Acta capitulorum nec non iudiciorum ecclesiasticorum selecta. Wyd. B. Ulanowski. T. 2. Kraków 1902.

Akta grodzkie i ziemskie z czasów Rzeczypospolitej Polskiej z Archiwum tzw. Bernardyńskiego we Lwowie. T. 1, 2, 5, 12, 14, 19. Wyd. O. Pietruski, X. Liske. Lwów 1868-1884.

Chronica Polonorum [...] Mathiae de Miechovia atrium et medicinae doctoris et canonici Cracoviensis. Cracoviae 1521.

Codex diplomaticus Silesiae. T. 2, 6. Wyd. W. Wattenbach, C. Grünhagen. Breslau 1865, 1859.

Codex epistolaris saeculi decimi quinti. T. 1. Wyd. A. SokoŁowski, J. SzujSKi. Kraków 1876.

Inventarium omnium et singulorum privilegiorum [...] in Archivo Regni in arce Cracoviensi. Wyd. E. Rykaczewski. Lutetiae Parisiorum-Berolini-Posnaniae 1862.

Jana Długosza Roczniki, czyli kroniki sławnego Królestwa Polskiego. Ks. 11 i 12, 12. Warszawa 2001, 2004, 2006.

Jana Łaskiego Liber Beneficiorum Archidiecezji Gnieźnieńskiej. T. 2. Wyd. J. Łukowski. Gniezno 1881.

Joannis Dlugossii Annales seu cronicae incliti Regni Poloniae. Lib. 11 et 12, 12. CracoviaeVarsaviae 2001, 2003, 2005.

Katalog dokumentów pergaminowych ze zbiorów Tomasza Niewodniczańskiego w Bittburgu. Oprac. J. Tomaszewicz, M. ZdaneK. Red. W. Bukowski. Kraków 2004.

Kodeks dyplomatyczny Polski. T. 4. Wyd. M. Вовоwsкi. Warszawa 1887.

Kodeks dyplomatyczny Wielkopolski. T. 10. Wyd. A. GĄSIORowski, T. JAsiŃski. Poznań 1993.

Lehns- und Besitzurkunden Schlesiens und seiner einzelnen Fürstenthümer im Mittelalter. Hrsg. C. Grünhagen, H. Markgraf. T. 1-2. Leipzig 1881-1883.

Matricularum Regni Poloniae Summaria. T. 1-4. Wyd. T. WierzBowski. Warszawa 19051919.

Necrolog des Kloster Czarnowanz. Hrsg. W. Wattenbach. „Zeitschrift des Vereins für Geschichte und Alterthum Schlesiens“"1856, Bd. 1.

Ratiborer Chronik. Hrsg. A. Weltzel. „Zeitschrift des Vereins für Geschichte und Alterthum Schlesiens" 1862, Bd. 4.

Silesiacarum rerum Scriptores. Hrsg. F.W. SommerSBERG. Bd. 1-2. Lipsiae 1729-1730.

Sinapius J.: Olsnographia oder Eigentliche Beschreibung des Oelßnischen Fürstenthums in Nieder-Schlesien. T. 2. Leipzig 1706.

Starodawne prawa polskiego pomniki. T. 6. Wyd. M. BoBRZYŃSKi. Kraków 1881.

Zbiór dokumentów małopolskich. Cz. 8. Wyd. I. SuŁkowsKa-Kuraś, S. Kuraś. WarszawaKraków 1975. 


\section{Opracowania}

Balzer O.: Genealogia Piastów. Kraków 1895.

BiskuP M.: Trzynastoletnia wojna z Zakonem Krzyżackim 1454-1466. Warszawa 1967.

Boniecki A.: Herbarz polski. T. 4. Warszawa 1901.

BRÜCKNER A.: Średniowieczna poezya tacińska w Polsce. Kraków 1892 („Rozprawy Akademii Umiejętności. Wydział Filologiczny” 1892, T. 16).

BRZEZIŃSKI W.: Koligacje matżeńskie możnowładztwa wielkopolskiego w drugiej połowie XIV i pierwszej połowie XV wieku. Wrocław 2012.

ČAPSKÝ M.: Vévoda Přemek Opavský (1366-1433). Ve službách posledních Lucemburki̊. Brno-Opava 2005.

ČAPSKÝ M.: Zlomený meč. Valentin Hrabatý, posledni z opavských Přemyslovců. „Dejiny a současnost" 2006, 2 (Přemyslovské dědictví).

Сносноlatý F.: Genealogie opavských Přemyslovců 1255-1525. „Listy Genealogické a Heraldické Společnosti v Praze. Acta Genealogica ac Heraldica“ 1978, ř. 6.

Cieplucha Z.: Z przeszłości ziemi kościańskiej. Kościan 1929.

DĄвrowski J.: Dzieje polityczne Ślaska w latach 1290-1402. W: Historia Ślaska od najdawniejszych czasów do 1400 r. Red. S. KutrzeBa. T. 1. Kraków 1933.

DworZACZeK W.: Genealogia. T. 2. Warszawa 1959.

DworzaczeK W.: Kościelecki Jan. W: Polski słownik biograficzny. T. 14. Wrocław-Kraków $1968-1969$.

GąsIorowski A.: Koligacje panów z Ostroroga w XV wieku. „Studia i Materiały do Dziejów Wielkopolski i Pomorza" 1980, T. 13, z. 2.

GĄSIOROwSKI A.: Starostowie wielkopolskich miast królewskich w dobie jagiellońskiej. Warszawa-Poznań 1981.

GĄSIOROWSKi A.: Szamotulski Wincenty Świdwa. W: Wielkopolski słownik biograficzny. Warszawa-Poznań 1981.

Gąsiorowski A.: Urzędnicy zarządu lokalnego w późnośredniowiecznej Wielkopolsce. Poznań 1970.

GąSIOROwsKi A.: Wielkopolska w ostatnich księgach Roczników Jana Dlugosza. Do Rozbioru krytycznego Annalium z lat 1385-1480. „Studia Źródłoznawcze” 1970, T. 15.

GórCZAK Z.: Rozwój majątków możnowładztwa wielkopolskiego w drugiej połowie XV i początkach XVI wieku. Studium z dziejów wielkiej własności ziemskiej. Poznań 2007.

Grabowski J.: Genealogia Piastów mazowieckich. Studia nad dziejami politycznymi Mazowsza, intytulacją i genealogia ksiażąt. Kraków 2012.

Grotefend H.: Stammtafeln der Schlesischen Fürsten bis zum Jahre 1740. Breslau 1889.

Hausdorf G.P.A.: Die Piasten Schlesiens. Breslau 1933.

JASIŃSKi K.: Rodowód Piastów mazowieckich. Poznań-Wrocław 1998.

JASIŃSKi K.: Rodowód Piastów ślaskich. Kraków 2007.

JuRek T.: Szamotulski Wincenty Świdwa, h. Nałęcz (zm. 1444). W: Polski słownik biograficzny. T. 46. Kraków 2010.

Kopetzky F.: Zur Geschichte und Genealogie der Přemyslidischen Herzoge von Troppau. „Archiv für österreichische Geschichte“ 1869, Bd. 41.

Korta W.: Matgorzata z Szamotut (zm. 1464). W: Polski stownik biograficzny. T. 19. Wrocław-Kraków 1974.

Kozıowska K.: Knižeci nekropole v klášteře sv. Ducha sester Dominikánek (v současnosti muzeum) w Ratiboři. „Vlastivědné listy“ 2003, roč. 29, č. 1. 
KrejČík T.: Jan. V: Biografický slovnik Slezska a severní Moravy. S. 4. Opava-Ostrava 1995.

KrejČík T.: Valentin. V: Biografický slovník Slezska a severní Moravy. S. 4. Opava-Ostrava 1995.

KuRTYKa J.: Latyfundium Tęczyńskie. Dobra i właściciele (XIV—XVII wiek). Kraków 1999.

Kurtyka J.: Tęczyńscy. Studium z dziejów polskiej elity możnowładczej w średniowieczu. Kraków 1997.

Michalowska T.: Literatura polskiego średniowiecza. Warszawa 2011.

Michalowska T.: Średniowiecze. Warszawa 2002.

MıKa N.: Ostatni Przemyślida - ksiązę Walentyn Garbaty. W: Czechy i Polska między Wschodem i Zachodem - średniowiecze i wczesna epoka nowożytna. Red. T. CIESIELSKI, W. IwAŃCZAK. Warszawa-Bellerive-sur-Allier 2016.

Mika N.: Przemyślidzi opawsko-raciborscy. „Ziemia Raciborska” 2006, T. 9.

Miкrot W.: Włodko z Danaborza, kasztelan nakielski i jego stosunki z Kazimierzem Jagiellończykiem. W: Album uczącej się młodzieży polskiej Józefowi Ignacemu Kraszewskiemu z powodu jubileuszu jego pięćdziesięcioletniej działalności literackiej. Lwów 1879.

Neustadt L.: Beiträge zur Genealogie schlesischer Fürsten. „Zeitschrift des Vereins für Geschichte und Alterthum Schlesiens" 1888, Bd. 22.

NowACKI J.: Analecta gnieźnieńskie IV. (Przed straceniem Włodka z Danaborza kasztelana i starosty nakielskiego). „Roczniki Historyczne” 1935, T. 11.

Nowak-Dıużewski J.: Okolicznościowa poezja polityczna w Polsce. Średniowiecze. Warszawa 1963.

Ostroróg Jan h. Nałęcz (zm. 1501). W: Polski słownik biograficzny. T. 24. Wrocław-Kraków 1979.

PAWIŃSKi A.: Jana Ostroroga żywot i pismo o naprawie Rzeczypospolitej. Warszawa 1884.

PietrzyK I.: Kancelaria i dokument Przemyślidów opawskich w XIV-XV wieku. Katowice 2008.

Prix D.: Vévoda Václav I. Opavský. Přispěvek k dějnám Opavského vévodstvípočátkem poslední čtvrtiny 14. století. „Acta historica et museologica Universitatis Silesiane Opaviensis” 1997, 3.

Rajman J.: Pogranicze ślasko-małopolskie w średniowieczu. Kraków 1998.

SEPIAL M.: Zastaw na dobrach ziemskich i dochodach królewskich w okresie panowania Władystawa III Warneńczyka na Węrzech (1440-1444). W: „Zeszyty Naukowe Uniwersytetu Jagiellońskiego", Nr 1219. Prace historyczne, z. 125. Kraków 1998.

Słownik historyczno-geograficzny województwa poznańskiego w średniowieczu. Cz. 1-4. Oprac. A. Gąsiorowski, T. Jurek, G. Rutkowska, P. Dembiński, K. Górska-Golaska, I. SKiersKa. Poznań 1982-2008.

Sperka J.: Do 1532 roku. W: Rybnik. Dzieje miasta i jego dzielnic. T. 1. Red. Z. HojkA, B. KLOCH. Rybnik 2017.

SPERKA J.: Jeszcze raz o okolicznościach zawarcia matżeństwa między Jadwiga Melsztyńska $i$ księciem opolskim Bernardem. W: Inter Regnum et Ducatum. Studia ofiarowane Profesorowi Janowi Tęgowskiemu w siedemdziesiąta rocznicę urodzin. Red. P. Guzowski, M. LiedKe, K. Boroda. Białystok 2018.

SPERKA J.: Matżeństwa Mikołaja $V$ księcia opawsko-raciborskiego, pana na Rybniku (zm. 1452 r.). W: Silesia - Polonia - Europa. Studia historyczne dedykowane Profesorowi Idziemu Panicowi. Red. J. Sperka. Bielsko-Biała-Cieszyn 2019.

Sperka J.: Otoczenie Wtadystawa Opolczyka w latach 1370-1401. Studium o elicie władzy $w$ relacjach z monarcha. Katowice 2006.

Sperka J.: Pszczyna i ziemia pszczyńska - dzieje polityczne do 1517 roku. W: Pszczyna. Monografia historyczna. Red. R. KaczmareK, J. SPerka. T. 1. Pszczyna 2014. 
SPerka J.: Tragiczne losy księcia rybnickiego Wacława III (zm. 1478). Epizod z dziejów rywalizacji między Jagiellonami a Maciejem Korwinem o koronę czeską. „Studia z Dziejów Średniowiecza" 2016, T. 20.

SPERKA J.: Władysław książę opolski, wieluński, kujawski, dobrzyński, pan Rusi, palatyn Węgier i namiestnik Polski (1326/1330_8 lub 18 maja 1401). Kraków 2012.

SPERKA J.: Z dziejów migracji rycerstwa śląskiego na ziemie Rusi Koronnej w końcu XIV $i$ w poczatkach XV wieku (wstępne rozpoznanie). W: Narodziny Rzeczypospolitej. Studia z dziejów średniowiecza i czasów wczesnonowożytnych. Red. W. BukowsKi, T. JUReK. T. 1. Kraków 2012.

SPERKA J.: Związki rodzinne króla Władysława Jagietty z książętami górnośląskimi i Luksemburgami w tle. W: Ojcowie i synowie. O tron, władze, dziedzictwo. W 700. rocznice narodzin Karola IV Luksemburskiego króla czeskiego i cesarza 1316-1378. Red. B. MożEJKo, A. PANer. Gdańsk 2018.

Starý M.: „,... pojav $k$ svatému manželství jich sestry dceru“. Marginálie ke genealogii slezských knižat a $k$ osudìm Krnovska na přelomu 15. a 16. Století. „Časopis Matice moravské“" 2018, R. 137, č. 1.

StarÝ M.: Sňatkové strategie opavských Přemyslovců. „Acta historica Universitatis Silesianae Opaviensis" 2012, T. 5.

Šusta J.: Počátky Lucemburské 1308-1320. Dvě knihy českých dějin. Kus středověké historie našeho kraje. Kniha 2. Vyd. 3. Praha 2002.

SzybKowski S.: Kościeleccy ze Skępego herbu Ogon i ich protoplaści. Studium z dziejów późnośredniowiecznej rodziny możnowładczej. Gdańsk 2018.

Szyвкоwski S.: Kujawska szlachta urzędnicza w późnym średniowieczu (1370-1501). Gdańsk 2006.

Szyвкоwski S.: Związki rodzinne Danaborskich z elitą urzędniczą Kujaw i ziemi dobrzyńskiej. „Roczniki Historyczne” 2000, T. 66.

SzYSZKa J.: Formowanie się dóbr monarszych w ziemi lwowskiej od połowy XIV do początku XVI wieku. Kraków 2016.

TęGOWski J.: Małżeństwo Wigunta Olgierdowicza w politycznych planach króla Władysława Jagietty. W: „Genealogia. Studia i Materiały Historyczne”. Red. M. GóRnY. T. 7. Wrocław 1996.

TĘGOwski J.: Pierwsze pokolenia Giedyminowiczów. Poznań-Wrocław 1999.

TĘGOWski J.: Władcy ślascy w polityce matżeńskiej króla Władysława Jagietty (1386-1412). W: Piastowie w kulturze i europejskich dziejach. Red. A. BARCIAK. Katowice 2007.

TYLus S.: Fundacje kościołów parafialnych w średniowiecznej archidiecezji lwowskiej. Lublin 1999.

Urzędnicy wielkopolscy XII-XV wieku. Spisy. Oprac. M. Bielińska, A. GĄSIOrowski, J. ŁoJKo. Wrocław-Kraków 1985.

Urzędnicy województwa ruskiego XIV—XVIII wieku. Spisy. Oprac. K. Przyboś. Wrocław 1987.

Weltzel A.: Geschichte der Stadt Sohrau in Oberschlesien. Sohrau 1888.

Weltzel A.: Geschichte der Stadt und Herschaft Ratibor. Ratibor 1881.

Weltzel A.: Historia miasta Żory na Górnym Ślasku. Żory 1997.

Weyssenhof-Brożkowa K.: Marcin ze Stupcy. W: Polski stownik biograficzny. T. 19. Wrocław-Kraków 1973.

WeysSenHOF-BrożKowa K.: Marcin ze Stupcy — poeta polskiego prerenesansu. „Eos” 1975, T. 63.

Wielkopolscy Ostrorogowie. Red. A. GĄsiorowsKi. Ostroróg 1998.

WiesiolowsKi J.: Ostroróg Jan. W: Wielkopolscy Ostrorogowie. Red. A. GĄSIORowsKi. Ostroróg 1998.

Zivier E.: Geschichte des Fürstentums Pless. Bd. 1. Kattowitz 1906. 


\title{
Jerzy Sperka
}

\author{
The Familial Connections between the Opava-Ratibor Přemyslid Family \\ and the Magnates of the Kingdom of Poland \\ until the Beginning of the $16^{\text {th }}$ Century
}

\section{Summary}

The analysis of primary sources concerning the Opava-Ratibor Přemyslid family in the context of their familial relationships with the representatives of the Polish magnates in the $15^{\text {th }}$ and the beginning of the $16^{\text {th }}$ century has allowed to issue significant corrections regarding the previous state of genealogical knowledge regarding several generations of the dynasty, namely: Wenceslaus II, Duke of Opava-Ratibor (died 1456), who married Małgorzata of Szamotuły and their progeny: Jan (died 1493), Anna, and most importantly: Helena, who married Jan Ostroróg; Katarzyna, who married Włodko of Danabórz, the Castellan of Nakło; and Mikołaj of Ratibor (died 1506), the son of Jan, who married Anna of Tęczyn. Moreover, it has become possible to organize the data concerning the history of the estates in the Greater Poland, Ruthenia and the Duchy of Ratibor, which were given as dowry. In addition, the above analysis allows to form more general conclusions, namely, that the magnate families achieved prestige by marrying into ducal families, while the latter were given the means to increase their wealth due to the large dowries bequeathed by the wives. Thus, both sides benefited politically. Noble women, on the other hand, by marrying dukes were given the opportunity to become and be regarded as duchesses, even after they returned to their families as widows.

Key words: the Přemyslid family, the Szamotulski family, the Dukes of Ratibor, Ratibor, Red Ruthenia

\section{Jerzy Sperka}

Familienbeziehungen der Přemysliden von Opava

der Stammlinie Ratibor mit dem Magnatentum des Königreiches Polen zu Beginn des 16. Jahrhunderts

\section{Zusammenfassung}

Die Analyse des Quellenmaterials, das die Ratiborer Přemysliden im Hinblick auf ihre Familienbeziehungen mit den Vertretern des polnischen Magnatentums im 15. Jahrhundert und am Anfang des 16. Jahrhunderts betrifft, lässt das bisherige Wissen um die genealogischen Fakten mehrerer Generationen dieser Dynastie wesentlich korrigieren. Gemeint sind hier: Herzog Wenzel von Ratibor (gest. 1456), der mit Małgorzata aus Szamotuły verheiratet war, und dann die Nachkommenschaft aus dieser Ehe: Jan (gest. 1493), Anna und vor allem Helena, die Jan Ostroróg heiratete, sowie Katarzyna, die mit Włodko aus Danabórz, dem Kastellan von Nakło, verheiratet war, und Nikolaus von Ratibor (gest. 1506), ein Sohn von Jan, der Anna aus Tęczyn heiratete. Es ist auch gelungen, das Wissen um das Schicksal von Gütern zu ordnen, die zur Mitgift in Großpolen, Ruthenien und im Herzogtum Ratibor wurden. Aus der vorliegenden Analyse sind auch folgende allgemeinen Schlussfolgerungen zu ziehen: die Eheschließung mit den herzoglichen Familien ermöglichte den Magnatenfamilien, ein großes Prestige zu erlangen, die Ehe mit einer Edelfrau aus der Magnatenfamilie bedeutete hingegen für die herzogli- 
che Seite vor allem die Möglichkeit, ihre finanzielle Situation aufgrund einer von der Ehefrau eingebrachten entsprechend großen Mitgift zu verbessern. Zweifelsohne brachten solche Ehen auch die politischen Vorteile für beide Seiten. Die Edelfrauen, die Herzoge heirateten, wurden dagegen zu den vollberechtigten Herzoginnen und mit solch einem Titel wurden sie angesprochen, auch wenn sie schon als Witwen in die Heimat, nach Polen, zurückkehrten.

Schlüsselwörter: Přemysliden, Familie Szamotulski, Herzoge von Ratibor, Ratibor, Kronruthenien 